\title{
The effects of sovereign rating drifts on financial return distributions: Evidence from the European Union
}

\author{
Hung Do ${ }^{\mathrm{a}}$, Robert Brooks ${ }^{\mathrm{a}}$, Sirimon Treepongkaruna ${ }^{\mathrm{b}}$, Eliza $\mathrm{Wu}^{\mathrm{c} 1}$ \\ ${ }^{a}$ Department of Econometrics and Business Statistics, Monash University, Australia \\ ${ }^{b}$ Accounting and Finance, UWA Business School, The University of Western Australia, Australia \\ ${ }^{c}$ Finance Discipline Group, UTS Business School, University of Technology Sydney, Australia
}

\begin{abstract}
We develop a framework that allows a multivariate system of long memory processes to be conditional on specific regimes to investigate the effects of credit rating agencies (CRAs)' sovereign credit re-ratings on European stock and currency return distributions over the period from 1996 to 2012. We find evidence across rating regimes to support the usefulness of our proposed model in accommodating both long memory and regime switching features. Furthermore, we reveal that the total effects (both direct and indirect forces) of sovereign credit assessments on the first four realized moments of return distributions can be different to their direct effects on individual moments. Thus, we find the rank orders among the three major CRAs to differ for each realized moment and asset market.
\end{abstract}

Keywords: Sovereign credit ratings; credit rating agencies; intraday data; higher moments; Markov regime switching; long memory

JEL classification: C32, F30, G15.

\footnotetext{
${ }^{1}$ Corresponding author. Tel: +61-2-95143905

Email addresses: hung.do@monash.edu (Hung Do), robert.brooks@monash.edu (Robert Brooks), sirimon.treepongkaruna@uwa.edu.au (Sirimon Treepongkaruna), eliza.wu@uts.edu.au (Eliza Wu).
} 


\section{Introduction}

Sovereign credit ratings, which publicly reveal opinions of specialist information intermediaries about the credit quality of a national government, are expected to influence the behavior of asset prices, especially during periods of market uncertainty and financial instability. Yet, the Credit Rating Agencies (CRAs) that provide this information, have often been criticized for their slow responses to financial crises as well as their inability to forewarn market participants (see Mora, 2006 and Gorton, 2008). It is, therefore, necessary to assess the impact of credit rating decisions provided by CRAs on the behavior of financial markets.

This paper develops a new approach to accurately capture the impact of sovereign credit assessments on financial return distributions. Focusing on financial return distributions enables an improved understanding of financial market participants reaction to sovereign ratings information and can also better inform other financial decisions for risk management and asset allocation purposes. The dynamics of higher return moments such as variance, skewness and kurtosis are documented to influence asset prices (see among others, Harvey and Siddique, 2000, Athayde and Flôres, 2003 and Mandelbrot and Hudson, 2004). The asymmetry and more generally, the tail behaviour of return distributions are known to be important for asset pricing and investment management. Yet the extant literature has traditionally examined the effect of sovereign rating changes on the first moment of asset return distributions (see for example, Brooks et al., 2004, Gande and Parsley, 2005, Ferreira and Gama, 2007; Hill and Faff, 2010a, Alsakka and ap Gwilym, 2012a,b) or asset correlations during financial crises (Chiang et al., 2007) but there is a dearth of attention on the impacts of credit rating changes on higher asset return moments. A potential reason for this void in the literature is the limitation of the parametric methods used in estimating the conditional higher moments ${ }^{2}$. In recent times, an increasing availability of intra-day data has

\footnotetext{
${ }^{2}$ Due to the limited availability of high frequency data, the higher moments were often estimated conditionally based on the well-known Generalized Autoregressive Conditional Heteroskedastic (GARCH) models and its variants. The
} 
provided a better alternative for measuring the higher moments of asset returns using nonparametric methods. The use of intraday data compared to daily data can give us a better representation and more robust estimate of actual asset price behavior (see for instance, Andersen et al., 2003).

In this paper, realized higher moments constructed from intraday returns, are treated as observable variables and, therefore, can be modelled directly within an econometric framework. Furthermore, we account for the properties of the realized higher moments in the empirical modelling process. Our preliminary analyses show that realized returns and skewness exhibit short memory behavior; whereas realized volatility and kurtosis are more likely to be long memory processes ${ }^{3}$. A long memory process is considered as an intermediate between two classical processes, the short-memory $(I(0))$ and the unit root process $(I(1))$. More precisely, it is defined corresponding to the case of a fractional degree of integration. Our proposed empirical model can accommodate fractional degrees of integration thereby capturing both short- and long-memory behavior in realized moments.

A significant number of studies have modelled sovereign credit rating transitions due to its critical role in modern credit risk management, valuation and international asset allocation (see among others, Bangia et al., 2002, Lando and Skødeberg, 2002, Fuertes and Kalotychou, 2007 and Hill et al., 2010b). The estimation of the rating transition probabilities matrix has indicated a regime switching behavior in credit ratings which needs to be accounted for in the modelling of sovereign

estimates of conditional volatility, skewness and kurtosis, therefore, rely heavily on these models' underlying assumptions. In addition, the problem is magnified within a multivariate system due to the large number of parameters that need to be estimated for extracting the outputs of conditional higher moments.

${ }^{3}$ Figure 3 illustrates the long memory behavior of realized volatility and kurtosis since their autocorrelations die out slowly and their spectral densities are unbounded at the origins; whereas, the realized return and skewness evolve as short memory processes because of their immediate died out autocorrelations and their bounded spectral densities at the origins. 
credit ratings' financial market impacts. In essence, credit ratings, either in levels or first differences (i.e., ratings changes), can be categorised into regimes (states), for example, states of ratings level can be defined as each of its letter designations (AAA, AA+,..); whereas, states of ratings changes may include stable (i.e. no change), downgrades or upgrades. The consideration of rating regimes (or trends in rating changes which we call 'drifts') is both useful and novel as this is consistent with investors' use of mental accounting in behavioral finance (Hirschleifer, 2001). Investors are likely to respond differently to rating revisions depending on the phase of the credit rating cycle and this is supported by the established asymmetric reactions of stock and currency market returns to rating downgrades relative to upgrades (Brooks et al., 2004). Hence, we develop an empirical framework that not only allows a flexible set of fractional degrees of integration for endogenous variables as mentioned earlier but that also captures the perceived regime switching behavior of sovereign credit ratings.

Our study contributes a new empirical framework to the current literature on the market impact of sovereign ratings. We allow a multivariate system of long memory processes to be conditioned on observable regimes that are based on the characteristics of sovereign credit quality assessments across the European region to account for common ratings information. It is conceivable that investors within the European Union (EU) would not only respond to credit assessments for their own national market but also those given for other EU countries. By accommodating both the long range dependencies of realized higher moments and the regime switching feature of common sovereign credit ratings information, the properties of these measures can be properly accounted for. The necessity of including these features within one framework has been supported in the recent literature, for instance, Diebold and Inoue (2001), Haldrup and Nielsen (2006) and Haldrup et al. (2010). Our approach is distinguished from existing models as it also allows for the presence of exogenous variables. This feature is important for assessing the effects of sovereign ratings which are not determined by the system of endogenous variables (i.e. the realized moments). Likewise, the feature is also useful as it allows many control variables to be 
included alongside sovereign credit assessments. Furthermore, we differentiate our approach further by using an alternative estimation procedure. The proposed technique, which concentrates the likelihood function on fractional degrees of integration, may help to facilitate our model in instances with higher dimensions since the objective function is numerically optimized over a smaller number of parameters in comparison with existing techniques.

We illustrate our new approach by empirically investigating the impact of sovereign credit assessments on European stock and foreign exchange (FX) return distributions. Alsakka and ap Gwilym (2013) provided evidence that sovereign credit assessments presented important signals of impending fiscal problems for currency market participants during in the European Debt Crisis up to 2010. We examine a longer period from January 1996 to July 2012, to cover the lead up to the introduction of the Euro as well as the height of the European sovereign debt crisis (hereafter, EDC) in 2011-2012 when the European Central Bank (ECB) was forced to intervene in European financial markets with a long term refinancing operation (LTRO) to inject liquidity and lower borrowing costs. Previous studies on the EDC like Calice et al. (2013) have documented widening credit spreads up to 2010 across Europe but the subsequent developments in European financial markets are less clear. Not surprisingly, all CRAs have been particularly active in downgrading European sovereigns during the recent debt crisis with on average, nearly $70 \%$ of all rating downgrades in our sample taking place since December 2008 (the onset of the EDC) (see Fig. 1).

We contribute comprehensive and new evidence of sovereign rating impacts on European financial markets during the EDC. We employ sovereign ratings data from Standard and Poor's, Moody's and Fitch - the three main CRAs in the world - in order to find out which agency has the greatest impact on financial return distributions via their first four realized moments. Although previous studies have indicated the largest impact is from Standard and Poor's (e.g., Reisen and Maltzan, 1999, and Brooks et al., 2004), recent activities of the CRAs during the EDC may change their rank orders. In line with this view, Alsakka and ap Gwilym (2012a, 2013) find that over the period from 1994-2010, Fitch’s sovereign credit signals induced the most timely currency market 
responses. In addition, previous studies investigated the issue based on causality tests and conducted event studies, which may only capture the direct effects of the CRAs' re-rating activities. We argue that the market impact of the CRAs should be measured in terms of their total effects, which include both direct and indirect forces. In a multivariate framework, where the inter-relationships among realized moments are captured, we define the indirect effects of the CRAs on a realized moment as the spillover effect that goes through other realized moments. This effect has been ignored in the literature but is important for gauging the full effects of sovereign credit assessments on financial return distributions. Lastly, in this paper, we further contribute to the literature by developing a tool that can capture the total effects of the CRAs to reveal which agency elicits the greatest market reactions (i.e., has the most influence on financial return distributions in our context). We believe this is the first study to distinguish between the direct and indirect effects of credit rating agencies' actions within financial markets and it is important to consider both manifestations on financial market stability.

The remainder of this paper is organized as follows. We describe the data construction in section 2. Section 3 proposes our new econometric model and its estimation procedure. We discuss the findings of our empirical analysis of the European financial markets in section 4. An impulse response of a transfer function is developed to reveal the most powerful CRA in section 5. Finally, we conclude our research in section 6 .

\section{Data}

We capture 5-minute intraday stock and FX market prices in some European Union (EU) countries from the Thomson Reuters Tick History (TRTH) database provided by the Securities Industry Research Centre of Asia-Pacific (SIRCA). By using 5-minute intraday data, we can minimise the problem of measurement error due to a reduction of microstructure biases ${ }^{4}$. The

\footnotetext{
${ }^{4}$ It is commonly known that microstructure biases (e.g., bid-ask bounce, price discreteness and nonsynchronous trading) cause measurement errors in the computation of realized volatility. However, Andersen et al. (2001) demonstrated that
} 
sample period studied is from January 1996 to July 2012, which covers the period from pre- Asian Financial Crisis until the recent European Sovereign Debt crisis (EDC). We employ the FX data quoted against the USD from 21 countries: Austria, Belgium, Bulgaria, Cyprus, Czech, Denmark, France, Germany, Greece, Hungary, Ireland, Latvia, Malta, Netherlands, Poland, Portugal, Romania, Slovakia, Spain, Sweden and the United Kingdom. However, due to limited availability of the high frequency data, our dataset for stock markets only consists of 10 stock market indices from within the European Union (EU), including Austria, France, Germany, Greece, Hungary, Ireland, the Netherlands, Romania, Spain and the United Kingdom.

In addition, we employ historical long-term foreign currency sovereign credit rating and credit outlook and watches from three leading CRAs - Standard and Poor's, Fitch and Moody's. This will enable an assessment on which CRA influences European stock market returns the most via its sovereign rating actions. Due to the irregular timing of ratings announcement, we focus our analysis on a monthly basis. We follow the approach of Gande and Parsley (2005) and Ferreira and Gama (2007) among others to transform the sovereign rating and credit outlook and watches into linear scores $^{5}$. We summarize all rating news released during each month using the comprehensive credit rating (CCR) measure ${ }^{6}$. Figure 1 illustrates how active the CRAs are in re-rating EU sovereign obligors. As can be seen, the CRAs have more often upgraded than downgraded EU countries over the entire sample period but not surprisingly most of the downgrade news on EU nations were released during the most recent sovereign debt crisis (around $70 \%$ of all downgrade rating news in our sample). Among the three CRAs, Fitch seems to be the least active agency in downgrading EU sovereigns; whereas, the number of upgrades released by Moody's for EU countries is the smallest

\footnotetext{
simulations of the 5-minute sampling interval produce mean square errors relatively close to the optimal interval. Besides, the use of 5-minute data to construct realized skewness and kurtosis is suggested by Amaya et al. (2013).

${ }^{5}$ Details will be available upon request.

${ }^{6}$ The CCR is calculated as the sum of linearized sovereign credit ratings and the credit outlook/watches following the approach of Gande and Parsley (2005).
} 
suggesting that they are the most conservative of the major CRAs. Overall, the absolute number of rating announcements has indicated that Standard and Poor's can be considered as the most active rating agency for countries in the EU (corroborating with prior studies that compare across rating agencies such as Brooks et al., 2004) ${ }^{7}$.

\section{[Insert Figure 1 here]}

To construct a proxy for the opinion of a CRA about the sovereign credit quality of the EU overall, we utilise the sovereign rating drift measure, which is the average change in credit quality across all EU member countries. The rating drift across the EU can be calculated for each CRA as,

$$
S R D_{t}=\frac{\sum_{i=1}^{m} \Delta C C R_{i t}}{m}
$$

where $\Delta C C R_{i t}$ is the first difference of the CCR measure of country $i$, and $m$ is the number of countries used to construct the rating drift. Since we aim to assess the opinion of a CRA about the whole EU overall, we include historical sovereign ratings data of all $27 \mathrm{EU}$ countries to construct the drift measure. The sovereign rating drift adequately reflects the view of a CRA on the average trend in the credit quality of all sovereign obligors in the EU region as a whole. The plots of the sovereign credit rating drifts for the three major CRAs shown in Figure 2 indicate that the rating drifts can be classified into three observable regimes or states over time, which are zero, positive and negative zones. These three zones can be inferred as the regimes of stable, upward and downward trends in sovereign credit quality across the EU as perceived by each of the CRAs. Furthermore, it can be observed that most of the negative rating drifts are in the period of the sovereign debt crisis, consistent with what has been shown in Figure 1. We can, therefore, consider the regime of downward sovereign credit quality as primarily the episode of the European sovereign debt crisis (EDC).

\footnotetext{
${ }^{7}$ Over the entire sample period, Standard and Poors released 112 downgrades and 124 upgrades. Meanwhile, Moody’s made 109 downgrades and 109 upgrades. Alongside these, Fitch announced 91 downgrades and 115 upgrades.
} 
[Insert Figure 2 here]

To model the stock market and FX return distributions, we construct their higher moments based on intraday returns rather than employing daily close to close prices since the use of intraday data is widely documented to provide more consistent and efficient estimates (see Andersen and Bollerslev, 1998, Barndorff-Nielsen and Shephard, 2001 and Andersen et al., 2003 among others).

The daily realized returns constructed from intraday returns are identical to the usual daily returns calculated from daily close to close prices,

$$
r_{t}=\sum_{i=1}^{D} r_{i, t}
$$

where $r_{i, t}$ denotes the $i$ th 5 -minute logarithmic return during day $t$ and $D$ denotes the total number of 5-minute logarithmic return intervals during any trading day.

We follow Andersen et al. (2003) and Amaya et al. (2013) to define the realized volatility $\left(R V_{t}\right)$, realized skewness $\left(R S_{t}\right)$ and realized kurtosis $\left(R K_{t}\right)$ respectively as ${ }^{8}$,

$$
\begin{gathered}
R V_{t}=\sum_{i=1}^{D} r_{i, t}^{2} \\
R S_{t}=\frac{\sqrt{D} \sum_{i=1}^{D} r_{i, t}^{3}}{R V_{t}^{3 / 2}} \\
R K_{t}=\frac{D \sum_{i=1}^{D} r_{i, t}^{4}}{R V_{t}^{2}}
\end{gathered}
$$

To facilitate empirical testing, the monthly realized measures are then constructed as averages of corresponding daily realized series.

We graph the sample autocorrelations and spectral densities of realized returns, (logged) realized volatility, realized skewness and (logged) realized kurtosis for a lag of 50 months in Figure

\footnotetext{
${ }^{8}$ The properties of realized volatility as defined in Eq. (3) are well analyzed in the literature (e.g., Andersen and Bollerslev, 1998 and Andersen et al., 2003). Meanwhile, the limits of realized skewness and kurtosis under the forms of Eq. (4) and Eq. (5) are recently assessed in Amaya et al., (2013).
} 
$3^{9}$. There is evidence of long memory behavior in the realized volatility and realized kurtosis series (ie., second and fourth moments) revealed by the slow hyperbolic autocorrelation decay and the most mass at the zero frequency of the spectral densities. Meanwhile, the sample autocorrelations of realized return and realized skewness fluctuates around zero during the displacement of 50 months, exhibiting the property of short memory processes.

\section{[Insert Figure 3]}

\section{Econometric modelling}

The properties and features of the four realized moments of financial returns and the sovereign rating drifts discussed in the previous section, motivate us to develop a flexible multivariate framework that can capture both long memory and regime switching behavior in these series.

Although there have been some studies debating the interchange between long memory and non-linear models ${ }^{10}$, it is necessary in our case to simultaneously accommodate both long range dependencies and regime switching behavior in order to adequately account for the properties of our variables of interest. The recent literature also supports the importance of including these features within a single framework, for instance, Diebold and Inoue (2001), Haldrup and Nielsen (2006) and Haldrup et al. (2010). In our case, the sovereign rating drifts are clearly distinguished by three separate regimes, which represent the periods of stable, upward and downward trends in sovereign credit quality ${ }^{11}$. In the stable period, sovereign rating drift has no impact on the financial return distribution as it is equal to zero. On the other hand, in the upward and downward regimes,

\footnotetext{
${ }^{9}$ We utilize the natural logarithm of realized volatility and kurtosis in our analysis consistent with the extant literature (e.g., Andersen and Bollerslev, 1998 and Andersen et al., 2003). Furthermore, the use of realized logarithmic volatility and kurtosis help us to avoid the non-negativity conditions in modeling. Therefore, when we refer to the realized volatility and kurtosis measures, they are in natural logarithmic forms.

${ }^{10}$ See for example, Granger and Ding (1996), Bos et al. (1999) and Granger and Hyung (2004).

${ }^{11}$ We can also interpret these regimes as the periods in which CRAs release good news and bad news regarding sovereign credit quality across the EU.
} 
the impact of sovereign ratings drift on financial return distributions and the characteristics of the financial return distribution itself can be very different. Accordingly, the long memory behavior of the realized moments of asset returns should not be fixed across the three regimes. Instead, we allow long memory behavior under the form of fractional integration to vary across these regimes of sovereign rating drifts. That is, to examine how financial return distributions behave during the periods of upward and downward rating drifts, we consider the ex-ante regimes that are defined by the direction of the sovereign rating drifts.

We utilise a multivariate long memory model with exogenous variables that are allowed to switch between different regimes. We model the realized moments of asset returns as endogenous variables in the system and we take the view that the sovereign ratings drift is not necessarily explained by the system of those realized moments. This assumption is supported by the myriad of prior studies showing the significant market impact of sovereign credit ratings information (see inter alia, Alsakka and ap Gwilym, 2012a, Brooks et al., 2004, and Hill and Faff, 2010a). The sovereign ratings drift is rather determined by public information as well as the private information owned and subjectively assessed by the CRAs. Therefore, we treat the sovereign ratings drift as an exogenous variable, which defines the states (regimes) and may help to explain the realized returnbased measures. Our model is different to the existing models in the literature (e.g., Haldrup and Nielsen, 2006 and Haldrup et al., 2010) in the sense that it allows for the existence of exogenous variables. We further distinguish our model by proposing a different technique used in the estimation procedure. This technique enables our model to be applicable for a higher dimensional system, which is also an advantage over existing models as we can model the first four realized return moments simultaneously. Instead of numerically optimizing the objective likelihood function with regards to all parameters as in the literature, we further concentrate the objective function with regards to the degrees of fractional integration. Hence, the numerical optimization procedure is much faster and, perhaps, more reliable than previously possible.

\subsection{Model specification and assumptions}


Let the $K$-dimensional time series, $Y_{t}=\left(Y_{1 t}, \ldots, Y_{K t}\right)^{\prime}$, follow a Markov Regime Switching and Fractionally Integrated Vector Autoregressive model with $n$ exogenous variables (MS-FIVARX), $R_{t}=\left(R_{1 t}, R_{2 t}, \ldots, R_{n t}\right)^{\prime}:$

$$
A^{\left(s_{t}\right)}(L) D^{\left(s_{t}\right)}(L) Y_{t}=\nabla^{\left(s_{t}\right)} R_{t}+\varepsilon_{t}, \quad t=1,2, \ldots, T
$$

We define $s_{t} \in\{1,2, \ldots, M\}$ as the observable regime variable which is characterized by the behavior of one of the exogenous variables $R_{t}$ and follows an ergodic $M$-state Markov chain process with a $(M \times M)$ irreducible transition probability matrix, $\mathrm{P}=\left\{p_{i j} ; i, j=1,2, \ldots, M\right\}$. We define $p_{i j}=\operatorname{Pr}\left(s_{t+1}=j \mid s_{t}=i\right)$ and $\sum_{j=1}^{M} p_{i j}=1, \forall i, j \in\{1,2, \ldots, M\}$. In other words, $p_{i j}$ is the probability that a regime $i$ is followed by a regime $j$.

The operator, $A^{\left(s_{t}\right)}(L)=I_{K}-\sum_{i=1}^{p} A_{i}^{\left(s_{t}\right)} L^{i}$, where $p$ is the lag order of the lag polynomial and $A_{i}^{\left(s_{t}\right)}$ is the $(K \times K)$ matrix of coefficients associated with the endogenous variables. $\nabla^{\left(s_{t}\right)}$ is the $(K \times n)$ matrix of coefficients associated with the exogenous variables. The operator $D^{\left(s_{t}\right)}(L)$ is a diagonal $(K \times K)$ matrix formed as, $D^{\left(s_{t}\right)}(L)=\operatorname{diag}\left\{(1-L)^{d_{1}\left(s_{t}\right)},(1-L)^{d_{2}\left(s_{t}\right)}, \ldots,(1-L)^{d_{K}\left(s_{t}\right)}\right\}$.

We can employ the binomial expansion to operationally generate the term $(1-L)^{-d_{j}\left(s_{t}\right)}$ as,

$$
(1-L)^{-d_{j}\left(s_{t}\right)}=\sum_{i=0}^{\infty} \frac{\Gamma\left(i+d_{j}\left(s_{t}\right)\right)}{\Gamma\left(d_{j}\left(s_{t}\right)\right) \Gamma(i+1)} L^{i}=\sum_{i=0}^{\infty} \psi_{i}^{d_{j}\left(s_{t}\right)} L^{i}
$$

where $\Gamma$ (.) is the gamma function; $\psi_{0}^{(0)}=1$, and $\psi_{i}^{(0)}=0$, for $i \neq 0$.

As in the representation of the MS-FIVARX, all the coefficient matrices, the degrees of fractional integration as well as the variance - covariance matrix of error terms are assumed to be regime dependent, which means that they are conditional on $s_{t}$, for example, 


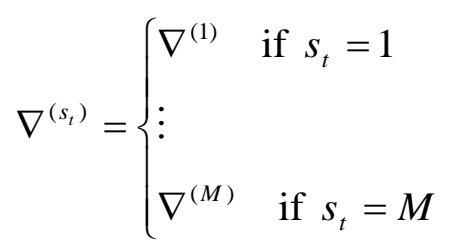

To ensure the adequacy, stationarity and to avoid the multicollinearity problems, the following additional assumptions have been made for our MS-FIVARX model:

Assumption 3.1: $\varepsilon_{t} \mid s_{t} \sim N\left(0, \Sigma_{\varepsilon}^{\left(s_{t}\right)}\right) ; \Sigma_{\varepsilon}^{\left(s_{t}\right)}=\left\{\sigma_{i j}^{\left(s_{t}\right)} ; i, j=1,2, \ldots, K\right\}$ are $(K \times K)$ positive definite matrices, $E\left(\varepsilon_{r} \varepsilon_{s}^{\prime} \mid s_{t}\right)=0$, for all $r \neq s$.

Assumption 3.2: All the roots of $\left|A^{\left(s_{t}\right)}(z)\right|=\left|I_{K}-\sum_{i=1}^{p} A_{i}^{\left(s_{t}\right)} z^{i}\right|=0$ fall outside the unit circle and $d_{j}^{\left(s_{t}\right)} \in(-0.5,0.5)$ for all $j=1,2, \ldots, K$.

Assumption 3.3: $Y_{t}$ has no deterministic trend. $Y_{t-1}, Y_{t-2}, \ldots, Y_{t-p}$ are not perfectly collinear and each element of $R_{t}=\left(R_{1 t}, R_{2 t}, \ldots, R_{n t}\right)^{\prime}$ is independent of each other.

\subsection{Estimation of transition probabilities}

Since the regime variable $s_{t}$ is assumed to be observable and determined by the behavior of the exogenous variable $R_{t}$, we may exploit $R_{t}$ to count the number of the observations in each regime as well as the number of transitions among regimes. These figures subsequently can be used to estimate the transition probability matrix P. Therefore, the maximum likelihood estimates (MLEs) of the transition probabilities are simply given as,

$$
p_{i j}=\frac{n_{i j}}{\sum_{m=1}^{M} n_{i m}}, \quad \forall i, j \in\{1,2, \ldots, M\}
$$

where $n_{i j}$ is the number of times that we observe a regime $i$ that is followed by a regime $j$.

\subsection{Estimation of the model's parameters}

We obtain the estimates of remaining parameters in the model by using the quasi maximum likelihood via the concentrated log-likelihood function (CLF). For a specific regime, model 
specification (6) follows a Fractionally Integrated Vector Autoregressive framework with exogenous variables (FIVARX). Hence, the CLF of our MS-FIVARX model in a specific regime can borrow the form of the CLF of a FIVARX model.

For simplicity, we ignore the term $s_{t}$ in constructing the CLF of a MS-FIVARX model in a specific regime since it is in fact under the representation of a FIVARX model. Let us consider,

$$
A(L) D(L) Y_{t}=\nabla R_{t}+\varepsilon_{t}, \quad t=1,2, \ldots, N
$$

Further, we assume that the $p$ pre-sample values of each endogenous variable, $Y_{-p+1}, \ldots, Y_{0}$, are available. The following notations are employed to facilitate our derivation,

$$
\begin{gathered}
X_{t}=D(L) Y_{t}, \underset{(K \times N)}{X}=\left(X_{1}, X_{2}, \ldots, X_{N}\right), \underset{(K \times(K p+n))}{B}=\left(A_{1}, A_{2}, \ldots, A_{p}, \nabla\right), \\
\underset{((K p+n) \times 1)}{Z_{t}}=\left[\begin{array}{c}
X_{t} \\
\vdots \\
X_{t-p+1} \\
R_{t}
\end{array}\right], \underset{((K p+n) \times N)}{Z}=\left(Z_{0}, \ldots, Z_{N-1}\right), \underset{(K \times N)}{U}=\left(\varepsilon_{1}, \varepsilon_{2}, \ldots, \varepsilon_{N}\right),
\end{gathered}
$$

\section{Lemma 3.1:}

Let the assumptions 3.1, 3.2, 3.3 hold and the variance-covariance matrix of error terms is written as a function of all parameters as,

$$
\Sigma_{\varepsilon}(d, B)=N^{-1} \sum_{t=1}^{N}\left(\varepsilon_{t} \varepsilon_{t}^{\prime}\right)=N^{-1} \sum_{t=1}^{N}\left(\left[A(L) D(L) Y_{t}-\nabla R_{t}\right]\left[A(L) D(L) Y_{t}-\nabla R_{t}\right]^{\prime}\right)
$$

For a given memory parameter $d,\left|\Sigma_{\varepsilon}(d, B)\right|$ can be denoted as $\left|\Sigma_{\varepsilon \mid d}(d, B)\right|$, then the following results hold,

$$
\left|\Sigma_{\varepsilon \mid d}(d, B)\right| \text { is minimized at } \hat{B}=X Z^{\prime}\left(Z Z^{\prime}\right)^{-1} \text {, and, }\left|\Sigma_{\varepsilon \mid d}(d, B)\right|_{\min }=\left|N^{-1}(X-\hat{B} Z)(X-\hat{B} Z)^{\prime}\right| \text {. }
$$

Following Lemma 3.1, we can obtain the CLF with regards to the memory parameter $d$ of a FIVARX model as presented in the proposition,

\section{Proposition 3.1:}


Let the assumptions 3.1, 3.2, 3.3 hold, the concentrated log-likelihood function with respect to the vector of memory parameters $d=\left(d_{1}, \ldots, d_{K}\right)^{\prime}$ of a FIVARX model is,

$$
l_{\text {FIVARX }}^{c}(d)=-\frac{K N}{2}[\ln (2 \pi)+1]-\frac{N}{2} \ln \left|\Sigma_{\varepsilon}(d)\right|
$$

where, $\Sigma_{\varepsilon}(d)=T^{-1} X\left(I_{N}-Z^{\prime}\left(Z Z^{\prime}\right)^{-1} Z\right) X^{\prime}$ and the estimators are obtained by,

$$
\hat{d}=\underset{d \in(-0.5,0.5)}{\arg \max } l_{F I V A R X}^{c}(d), \text { and } \hat{B}=\hat{X} \hat{Z}^{\prime}\left(\hat{Z} \hat{Z}^{\prime}\right)^{-1}
$$

According to Proposition 3.1, we can obtain the conditional log-likelihood functions of our MS-FIVARX model, apart from constants, for a specific regime $i$ as follows,

$$
I^{c}\left(d^{\left(s_{t}=i\right)}\right)=-\sum_{t=1}^{T} \frac{I\left(s_{t}=i\right)}{2} \ln \left|\sum_{\varepsilon}\left(d^{\left(s_{t}=i\right)}\right)\right|
$$

where $I\left(s_{t}=i\right)$ is the indicator function returning 1 if $s_{t}=i$ and 0 otherwise.

The full-sample CLF of a MS-FIVARX model with respect to the vector of memory parameters is given by $l^{c}(d)=\sum_{i=1}^{M} l^{c}\left(d^{\left(s_{t}=i\right)}\right)$.

Alternatively, we collect all the information of the regimes during the sample period in a $(M \times 1)$ vector, $\xi_{t}=\left[I\left(s_{t}=1\right), I\left(s_{t}=2\right), \ldots, I\left(s_{t}=M\right)\right]^{\prime}$, and, the variance-covariance matrices of error terms concentrated on $d^{\left(s_{t}\right)}, \Sigma_{\varepsilon}\left(d^{\left(s_{t}\right)}\right)$, for $M$ regimes in the $(K \times M K)$ matrix, $\Sigma=\left[\Sigma_{\varepsilon}\left(d^{\left(s_{t}=1\right)}\right), \ldots, \Sigma_{\varepsilon}\left(d^{\left(s_{t}=M\right)}\right)\right]$. We have the ultimate representation of the full-sample CLF of a MS-FIVARX model as ${ }^{12}$,

$$
I^{c}(d)=-\frac{1}{2} \sum_{t=1}^{T} \ln \left|\Sigma\left(\xi_{t} \otimes I_{K}\right)\right|
$$

\footnotetext{
${ }^{12}$ Detailed proofs of Lemma 3.1 and Proposition 3.1 as well as derivation to achieve the form of (10) are available upon request.
} 
At the first stage, the memory parameters $d^{\left(s_{t}\right)}$ can be obtained by numerically maximizing the $l^{c}(d)$ with respect to $d^{\left(s_{t}\right)}, \hat{d}^{\left(s_{t}\right)}=\underset{d \in(-0.5,0.5)}{\arg \max } l^{c}(d)$.

Remaining parameters $\hat{B}$ for each regime are extracted conditional on estimator $\hat{d}^{\left(s_{t}\right)}$ using the results obtained in Proposition 3.1.

\section{Empirical results}

We utilise our proposed model by employing realized return-based measures constructed in section 2 to investigate the impact of the sovereign ratings drifts on stock market and FX return distributions within the EU. Since the preliminary analyses performed in section 2 affirmed the short memory behavior of realized returns and skewness, we restrict their memory parameters to be zero. The fractional degrees of integration for realized volatility and kurtosis are allowed to vary across regimes. As discussed in previous sections, we distinguish the relationship between realized return moments and CRA sovereign rating changes into three regimes which are defined by the properties of the sovereign rating drifts. These regimes can be considered as the periods of stable, upward and downward assessments of sovereign credit quality, corresponding to zeros, positive and negative values on sovereign ratings drifts respectively. We focus on the results obtained in the upward and downward regimes. Also, as noted in section 2, the time series plots of the sovereign ratings drifts (Figure 2) indicate that the period of the EDC is prominent and covers almost the entire downward regime. We, therefore, consider the downward state as a representation of the European sovereign debt crisis.

More importantly, to facilitate the interpretation of the effects of downward sovereign rating drifts on each realized moment, we employ the absolute values of the downward drifts in modelling. Hence, a positive relationship between the drifts and the realized return in the downward regime, for example, can be interpreted as more negative assessments of sovereign credit quality will lead to an increase in the realized return consistent with the basic risk-return trade-off in Finance theory. 
We choose the optimal lag length $p$ for the model so that the innovations mimic the white noise processes and the parsimonious criteria is satisfied. We, therefore, end up with the lag length of order 1 for our models. This result is reasonable as both characteristics of the measures, the long memory and regime switching features, which may require a large number of lag orders have been captured by the specification of the proposed model. The estimated results show that all the roots fall outside the unit circle and the memory parameters are in the range from -0.5 to 0.5 , an indication of stationarity ${ }^{13}$.

\subsection{The transition probability matrices}

As the regimes are observable, we can easily calculate the estimates of transition probabilities for each regime according to formula (8). We present the estimated results of the transition probability matrices in Table 1.

\section{[Insert Table 1]}

The estimates indicate an average level of persistence of the regimes. The probabilities that the sovereign rating drifts stay in one regime are at most 0.5 . Among all, the probabilities of staying in the upward regime are the lowest (i.e., 0.25, 0.38 and 0.28 for the Standard and Poor's, Fitch and Moody's respectively). There is a relatively high likelihood of remaining in the stable state (i.e., 0.38, 0.48 and 0.49 for Standard and Poor's, Fitch and Moody's respectively) compared to either upward or downward states, consistent with the view that CRAs provide long-term assessments on sovereign credit quality and the practice of rating through the cycle. These figures in conjunction with the probabilities of residing in the upward regime, however, imply somewhat that the CRAs have not been active in re-assessing sovereign credit quality across the EU prior to the onset of the EDC. In contrast, there are relatively high levels of persistence in the downward regime (i.e., 0.45, 0.50 and 0.39 for Standard and Poor's, Fitch and Moody’s respectively) indicating that CRAs seem

\footnotetext{
${ }^{13}$ We do not report the full set of our estimation results to conserve space. However, full details are available upon request.
} 
to have learnt lessons from the Global Financial Crisis and have become more active in downgrading sovereign credit quality throughout the EDC.

\subsection{Impact of the sovereign credit assessments on financial return distributions}

In this section, we analyse the direct impacts of the sovereign ratings drift on each realized moment of the EU stock and FX return distribution by using the Granger Causality test. Hence, we extract the estimates of the vector $\nabla^{\left(s_{t}\right)}$ and their corresponding $t$-statistics. ${ }^{14}$

\section{Direct impacts on European stock and $F X$ realized returns}

We report the effects of sovereign credit quality assessments on realized returns across both the upward and downward regime in Table 2. As can be seen, the sovereign ratings drifts are likely to have insignificant impacts on stock market realized returns in both upward and downward regimes. This result implies that the overall assessments of CRAs on European sovereign creditworthiness have limited direct contribution to changes in realized stock market returns across the EU. However, if we focus on the direction instead of the significance of the relationship, we find a negative impact of the upward rating drifts on realized stock market returns while downward rating drifts tend to have positive effects. This finding is consistent with the basic risk-return trade off theory in Finance since the upward trend in the sovereign credit quality evaluation reveals a tendency of lower credit risk; whereas, the downward trend indicates increasing credit risk.

\section{[Insert Table 2]}

We find that realized FX returns react significantly to Standard and Poor's re-ratings in the upward regime but respond more to Moody's re-ratings in the downward regime (during the EDC). Interestingly, this result differs from previous studies in two ways. Firstly, our result indicates that FX returns react positively to only Standard and Poor's upward rating drift; whereas Alsakka and ap Gwilym (2010, 2013) find a dominant role of Moody’s positive news. Secondly, while Alsakka

\footnotetext{
${ }^{14}$ For the purpose of calculating the $t$-statistics, we obtain the asymptotic covariance matrix of the concentrated maximum likelihood estimates as the negative inverse of the observed Hessian matrix.
} 
and ap Gwilym (2013) report an association between negative rating news and significant currency depreciation, we find a positive impact of Moody's downward rating drift on FX return. Our result, nevertheless, is consistent with the basic risk-return trade off theory as noted previously. One possible explanation for our different results with the literature is our focus on the impact of the overall EU creditworthiness assessment, while previous studies look at the effect of sovereign ratings of individual countries. Hence, we contribute new evidence on sovereign rating impacts at a regional level to cater for the unique economic arrangement within the EU.

\section{Direct impacts on European stock market and FX realized volatility}

The effects of sovereign credit assessments on realized volatility across both upward and downward regimes are shown in Table 3. It can be observed that the sovereign rating drifts have limited impacts on both stock and FX realized volatility in the upward regime. However, there is more evidence of their significant effects in the downward regime. This result indicates that the assessments of the CRAs on sovereign credit quality across the EU have greater effects on the uncertainty and/or the dispersion of opinions with respect to the value of European stocks and currencies during the recent EDC.

\section{[Insert Table 3]}

As expected, we find a consistently negative relationship between the upward rating drifts and realized volatility in both stock and FX markets. Meanwhile, the downward rating drifts have significant and positive effects on realized volatility. The results unambiguously indicate that improvements in CRAs' assessments on sovereign credit quality across the EU reduces stock and FX market uncertainty; whereas continuing negative assessments will increase market uncertainty. This finding is consistent with the empirical results which we obtained in analysing the direct impacts of ratings drift on realized returns from the previous sub-section. The explanation for this consistency can be based on the risk-return trade off theory in Finance.

\section{Direct impact on European stock and FX realized skewness}


Table 4 reports the effects of sovereign credit assessments on realized skewness in stock and FX markets across both upward and downward regimes. For the stock market, we find that the case of Standard and Poor's sovereign ratings drift provides strong evidence of the direct effects in the upward regime; whereas, in the downward regime, more evidence of the direct effects is revealed for Fitch's sovereign ratings drift. This result indicates that Standard and Poor's assessments on sovereign creditworthiness within the EU have relatively broader impacts on the asymmetry of stock market return distributions during periods of financial stability. Meanwhile, Fitch has evidently played a more critical role in this regard during the recent EDC. In the FX market, we observe the reverse situation since Fitch's ratings delivers greater direct effects in the upward regime; whereas, Standard and Poors’ rating effects are stronger in the downward regime.

[Insert Table 4]

Interestingly, in terms of both stock and FX markets, we mostly find a positive relationship between sovereign ratings drift and realized skewness in both upward and downward regimes. Hence, regardless of the upward or downward direction, as long as the ratings drift changes (i.e., more rating news are released), the magnitude of the positive extreme returns in EU stock and FX markets is larger (more right-skewed).

\section{Direct impact on European stock and $F X$ realized kurtosis}

The effects of sovereign credit assessments on realized kurtosis across both upward and downward regimes are summarized in Table 5. We find limited evidence of significant effects in the upward regime but greater evidence of the significant relationship between sovereign ratings drifts and realized kurtosis can be found in the downward regime. Hence, the results show that the assessments of the CRAs on overall sovereign creditworthiness across the EU have greater impacts on the occurrence of extreme returns in stock and FX markets during the EDC.

\section{[Insert Table 5]}

In addition, we mostly find the negative relationship between the sovereign ratings drift and realized kurtosis in the downward regime; whereas, the upward rating drifts tend to positively affect 
realized kurtosis. These results indicate that an upsurge in the downward (upward) trend of the CRA's assessments on EU sovereign obligors will significantly lower (increase) the peak of stock and FX return distributions for European countries. This result is consistent with what we have found in the analysis of the direct impacts of sovereign credit assessments on realized volatility. This is because a return distribution with a lower (higher) peak corresponds to a distribution with more (less) return dispersion. Besides, as mentioned in the previous sub-section, we note that an increase in the downward (upward) rating drift will heighten (decrease) stock and FX market volatility across the EU.

\section{The most dominant credit rating agency}

The empirical results discussed so far confirm certain impacts of each CRA's sovereign ratings on financial return distributions via its first four realized moments. It, however, remains questionable which CRA has the largest effect on financial markets. In section 4, we assessed the direct impact of CRAs' assessments using Granger Causality tests. Yet, this method is not applicable to address the issue of dominance amongst the CRAs as this should be reflected by their total effects including both direct and indirect forces. Because of the inter-relationship among realized moments, which is also captured in our multivariate system, the indirect effects of the sovereign rating drifts on a realized moment is the spillover effect that goes through other realized moments in the system. In this section, we develop a tool, which we call the impulse response of a transfer function (IRTF), to capture those total effects of the CRAs' assessments. The IRTF describes how endogenous variables react when there is an exogenous shock to the exogenous variables. The function, therefore, is ideal for capturing the total responses of a financial return distribution to a change in the sovereign ratings drift since such a change is usually caused by a shock from outside arriving under the form of public or private information which is assessed by the CRAs.

\subsection{Impulse response of a transfer function}


Under the basic assumptions which have been made in previous sections, we can rewrite model specification (6) under an infinite moving average representation (MA( $\infty)$ ). Similar to what has been derived in Do et al. (2013), we can easily obtain:

$$
Y_{t}=\Phi_{*}^{\left(s_{t}\right)}(L) R_{t}+\Phi^{\left(s_{t}\right)}(L) \varepsilon_{t}
$$

where,

$$
\Phi_{*}^{\left(s_{t}\right)}(L)=\nabla^{\left(s_{t}\right)}+\sum_{h=1}^{\infty} \Phi_{h}^{\left(s_{t}\right)} \nabla^{\left(s_{t}\right)} L^{i} \text { and } \Phi^{\left(s_{t}\right)}(L)=I_{K}+\sum_{h=1}^{\infty} \Phi_{h}^{\left(s_{t}\right)} L^{i}
$$

The $(K \times K)$ coefficient matrix $\Phi_{h}^{\left(s_{t}\right)}$ can be calculated using the following relationship,

$$
\Phi_{h}^{\left(s_{t}\right)}=\left\{\begin{array}{ll}
\sum_{i=0}^{h} \Psi_{i}^{d\left(s_{t}\right)} \Pi_{h-i}^{\left(s_{t}\right)} & h=1,2, \ldots \\
\Pi_{0}^{\left(s_{t}\right)} & h=0
\end{array},\right.
$$

where $\Psi_{i}^{d\left(s_{t}\right)}$ is the diagonal $(K \times K)$ matrix with $\psi_{i}^{d_{j}\left(s_{t}\right)}$ (noted in formula (7)) as the $j^{\text {th }}$ element, and $\Pi_{i}^{\left(s_{t}\right)}$ is obtained according to the following recursive relationship,

$$
\Pi_{i}^{\left(s_{t}\right)}= \begin{cases}\sum_{j=1}^{i} \Pi_{i-j}^{\left(s_{t}\right)} A_{j}^{\left(s_{t}\right)} & i=1,2, \ldots, p \\ \sum_{j=1}^{p} \Pi_{i-j}^{\left(s_{t}\right)} A_{j}^{\left(s_{t}\right)} & i>p \\ I_{K} & i=0\end{cases}
$$

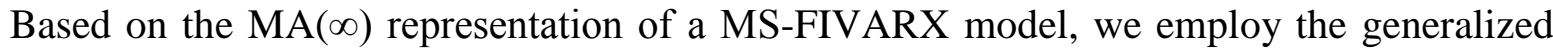
approach proposed by Koop et al. (1996) to develop our IRTF. The IRTF at a horizon $h$ is, therefore, defined as the difference between the conditional expectation of $Y_{t+h}$, given the information set available at time $t-1$ (after incorporating the effect of the shock on exogenous variables) and the conditional expectation without the effect of the shock,

$$
\operatorname{IRTF}_{h}=E\left(Y_{t+h} \mid R_{t}=\delta, \Omega_{t-1}\right)-E\left(Y_{t+h} \mid \Omega_{t-1}\right),
$$

where $\delta=\left(\delta_{1}, \ldots, \delta_{n}\right)^{\prime}$ is $(n \times 1)$ vector of exogenous shocks on the exogenous variables $R_{t}$. 
Under an additional assumption that $E\left(R_{t}\right)=0$, we ultimately obtain the full matrix of impulse responses of a transfer function as ${ }^{15}$,

$$
\operatorname{IRTF}_{h}^{\left(s_{t}\right)}=\Phi_{h}^{\left(s_{t}\right)} \nabla^{\left(s_{t}\right)} \Xi_{*}
$$

where $\Xi_{*}=\operatorname{diag}\left\{\delta_{1}, \delta_{2}, \ldots, \delta_{n}\right\}$ is a $(n \times n)$ diagonal matrix characterized by elements of the shocks to $R_{t}{ }^{16}$.

Accordingly, we can interpret the $(i, j)$ element of $\operatorname{IRTF}_{h}^{\left(s_{t}\right)}$ as the response of the $i^{\text {th }}$ endogenous variable at horizon $h$ (i.e., at time $t+h$ ) to a shock hitting the $j^{\text {th }}$ exogenous variable at time $t$.

It can be easily seen that under equation (11), the indirect effects of the exogenous shock in $R_{t}$ on $Y_{t}$ are captured in the matrix $\Phi_{h}^{\left(s_{t}\right)}$; whereas, the direct effects are captured by the matrix $\nabla^{\left(s_{t}\right)}$.

\subsection{Empirical results on impulse response analyses}

We calculate the IRTF based on a one standard deviation shock in the sovereign ratings drift as this is the usual choice in the literature featuring impulse response analyses. We report the average responses of EU stock market and FX realized moments to the shock in the sovereign ratings drift for 20 periods ahead in Figures 4 and 5, respectively.

\section{[Insert Figures 4 \& 5]}

As can be seen, Standard and Poor's assessments have the greatest impact on stock market realized returns and skewness for the first 5 periods ahead in the upward regime. This result is consistent with the literature, for example, Reisen and Maltzan, 1999, and Brooks et al., 2004, also find that the rating actions of Standard and Poor's affect stock market returns more than other CRAs. However, the case of higher moments has not been investigated to date. In our analysis, the

\footnotetext{
${ }^{15}$ We use the $\mathrm{MA}(\infty)$ representation of $Y_{t}$ to derive the difference between the two conditional expectations and obtain the final form of the IRTF accordingly. Since the steps involved are trivial, we skip to the results to conserve space.

${ }^{16}$ Following Koop et al. (1996) and Pesaran and Shin (1998), we set the unit shock as a one standard deviation shock.
} 
empirical results show that the sovereign rating drifts constructed from Fitch ratings have the largest effect on stock market realized volatility in the upward regime; whereas, the magnitude of effects on stock market realized kurtosis is not clearly distinguishable among the major CRAs.

In the most recent sovereign debt crisis represented largely by the downward regime, the rank of the CRAs regarding the magnitude of the effects on realized moments has changed. We find interesting results that Moody's assessments on overall EU sovereign creditworthiness have the greatest impact on almost all stock market realized moments around the first 5 periods. The only exception is the effects on realized volatility, for which Moody's shares the $1^{\text {st }}$ ranking with Fitch ratings since their effects are quite comparable.

In terms of the FX market, we consistently observe that Standard and Poors and Fitch's ratings drifts have the greatest impact on FX realized higher moments in both upward and downward regimes. Meanwhile, the magnitude of the effects on FX realized returns during the EDC is about five folds greater than in stable periods. These findings are in line with the findings of Alsakka and Gwilym (2012a, 2013) but we differ in identifying a strong impact for Standard and Poors as well as Fitch’s ratings when indirect effects on higher moments are considered.

In addition, we note that there is a contradiction in the result between the IRTF (in this section) and the Granger Causality test (in the previous section) in the case of the effects on realized returns in an upward regime. For example, we find a negative relationship between sovereign ratings drift and the stock market realized returns in the upward regime using the Granger Causality test. However, the IRTF confirms this is a positive relationship. The difference in result supports their complementary property. While the Granger Causality only tests the direct causal effect, the IRTF captures both the direct and the indirect effects and provides a more complete picture of the rating impacts. 


\section{Conclusions}

In this study we investigate the effects of trends in sovereign credit assessments on stock market and FX return distributions within the European Union (EU) via their first four realized return moments. To do so, we develop a multivariate framework to precisely capture the full effects of CRAs' sovereign credit assessments on financial return distributions by allowing endogenous long memory variables to be conditional on observable regime switching in exogenous variables. The model is motivated by the necessity to fully investigate the impacts of sovereign credit quality assessments on financial return distributions as there is a dearth of attention on the impacts of CRA announcements beyond the usual first and/or second moments of asset returns. The consistent and robust estimates of moments of the return distribution (i.e., the realized moments) exhibit long memory behavior whilst the regime switching feature of sovereign ratings has been widely documented. Thus, our proposed model is designed to capture both of these features in order to separately account for the properties of these variables of interest.

Our empirical results confirm the heterogeneous effects of rating actions across regimes, which are defined to correspond to the upward and downward trends in sovereign credit assessments by individual CRAs. Hence, these results illustrate the usefulness of the proposed model since misleading conclusions may be made if the process is not allowed to be conditional on separate states of creditworthiness. More specifically, we mostly find a negative relationship between the overall EU sovereign credit assessments and realized returns in the upward regime, yet the positive relationships are observed in the downward regime. These findings are consistent with the basic risk-return trade-off in finance theory, and are further confirmed by the results of sovereign rating impacts on realized volatility. The evidence mostly shows negative effects of rating drifts on realized volatility in the upward regime but positive effects in the downward regime. Furthermore, changes in the overall ratings trend (both upward and downward) results in stock and FX return distributions being more right-skewed. Meanwhile, in terms of realized kurtosis, we find an upsurge in the downward (upward) EU sovereign rating drifts will significantly lower (increase) the peak of 
the EU stock and FX return distributions. The finding is consistent with empirical results obtained in analysing the impacts on realized volatility.

In this paper, we also note that the total effects of the sovereign credit assessments on realized moments can be different from their direct effects alone. This is due to the indirect effects, which are caused by the inter-relationships and spillovers between the realized return moments. Therefore, we argue in this paper that the total effects, rather than the direct one, should be employed to investigate which CRA provides the greatest impact on financial return distributions. We find that the rank orders among the CRAs differ for each realized moment and asset market. In the periods of financial stability, the assessments of S\&P have the greatest effect on stock market realized returns and skewness; whereas Fitch's rating actions have the largest impact on stock market realized volatility across the EU. Meanwhile, Moody’s rating activities dominate during the recent European sovereign debt crisis. Besides, we consistently find that S\&P and Fitch share the $1^{\text {st }}$ rank order in having the largest effects on FX realized higher moments. This is possibly due to Fitch being the only major CRA based outside of the US. 


\section{References}

Alsakka, R., \& ap Gwilym, O. (2013). Rating agencies’ signals during the European sovereign debt crisis: Market impact and spillovers, Journal of Economic Behavior and Organization, 85, 144-162.

Alsakka, R., \& ap Gwilym, O. (2012a). Foreign exchange market reactions to sovereign credit news. Journal of International Money and Finance, 31, 845-864.

Alsakka, R., \& ap Gwilym, O. (2012b). Rating agencies’ credit signals: An analysis of sovereign watch and outlook. International Review of Financial Analysis, 21, 45-55.

Alsakka, R., \& ap Gwilym, O. (2010). Leads and lags in sovereign credit ratings. Journal of Banking and Finance, 34, 2614-2626.

Amaya, D., Christoffersen, P., Jacobs, K., \& Vasquez, A. (2013). Do realized skewness and kurtosis predict the cross-section of equity returns? Available at SSRN: http://ssrn.com/abstract=1898735.

Andersen, T. G., Bollerslev, T., Diebold, F. X., \& Labys, P. (2003). Modeling and forecasting realized volatility. Econometrica, 71, 579-625.

Andersen, T., \& Bollerslev, T. (1998). Answering the skeptics: Yes, standard volatility models do provide accurate forecasts. International Economic Review, 39, 885-905.

Andersen, T., Bollerslev, T., Diebold, F. X., \& Labys, L. (2001). The distribution of realized exchange rate volatility. Journal of the American Statistical Association, 96, 42-55.

Athayde, G., \& Flôres, R. (2003). Incorporating skewness and kurtosis in portfolio optimization: A multidimensional efficient set. In S. Satchell, \& A. Scowcroft, Advances in Portfolio Construction and Implementation (pp. 243-257). Butterworth-Heinemann Finance.

Bandorff-Nielsen, O. E., \& Shephard, N. (2011). Non-Gaussian Ornstein - Uhlenbeck - based models and some of their uses in financial economics. Journal of the Royal Statistical Society, Series B, 63, 167-241.

Bangia, A., Diebold, F. X., Kronimus, A., Schagen, C., \& Schuermann, T. (2002). Ratings migration and the business cycle, with applications to portfolio stress testing. Journal of Banking and Finance, 26, 445-474.

Bos, C., Franses, P., \& Ooms, M. (1999). Long memory and level shifts: re-analyzing inflations rates. Empirical Economics, 24, 427-449.

Brooks, R., Faff, R., Hillier, D., \& Hillier, J. (2004). The national market impact of sovereign rating changes. Journal of Banking and Finance, 28, 233-250.

Calice, G., Chen, J., \& Williams, J. (2013). Liquidity spillovers in sovereign bond and CDS markets: An analysis of the Eurozone sovereign debt crisis. Journal of Economic Behavior and Organization, 85, 122-143.

Chiang, T.C., Jeon, B.N., Li H., 2007. Dynamic correlation analysis of financial contagion: Evidence from Asian markets, Journal of International Money and Finance 26, 1206-1228.

Diebold, F., \& Inoue, A. (2001). Long memory and regime switching. Journal of Econometrics, 105, 131-159.

Do, H. X., Brooks, R. D., \& Treepongkaruna, S. (2013). Generalized impulse response analysis in a fractionally integrated vector autoregressive model. Economics Letters, 118, 462-465. 
Ferreira, M. A., \& Gama, P. M. (2007). Does sovereign debt ratings news spillover to international stock markets? Journal of Banking and Finance, 31, 3162-3182.

Fuertes, A. M., \& Kalotychou, E. (2007). On sovereign credit migration: a study of alternative estimators and rating dynamics. Computational Statistics and Data Analysis, 51, 3448-3469.

Gande, A., \& Parsley, D. C. (2005). News spillovers in the sovereign debt market. Journal of Financial Economics, 75, 691-734.

Gorton, G. (2008). Subprime panic. European Financial Management, 15, 10-46.

Granger, C., \& Ding, Z. (1996). Varieties of long memory models. Journal of Econometrics, 73, 61-77.

Granger, C., \& Hyung, N. (2004). Occasional structural breaks and long memory with an application to the S\&P 500 absolute stock returns. Journal of Empirical Finance, 11, 399421.

Haldrup, N., \& Nielsen, M. (2006). A regime switching long memory model for electricity prices. Journal of Econometrics, 135, 349-376.

Haldrup, N., Nielsen, F., \& Nielsen, M. (2010). A vector autoregressive model for electricity prices subject to long memory and regime switching. Energy Economics, 32, 1044-1058.

Harvey, C., \& Siddique, A. (2000). Conditional Skewness in asset pricing tests. Journal of Finance, $55,1263-1295$.

Hill, P., \& Faff, R. (2010a). The market impact of relative agency activity in the sovereign ratings market. Journal of Business Finance and Accounting, 37, 1309-1347.

Hill, P., Brooks, R. D., \& Faff, R. (2010b). Variations in sovereign credit quality assessments across rating agencies. Journal of Banking and Finance, 34, 1327-1343.

Hirshleifer, D. (2001). Investor psychology and asset pricing. Journal of Finance 56, 1533-1597.

Johansen, S. (1995). Likelihood-based inference in cointegrated vector auto-regressive models. New York: Oxford University Press.

Koop, G., Pesaran, M. H., \& Potter, S. M. (1996). Impulse response analysis in nonlinear multivariate models. Journal of Econometrics, 74, 119-147.

Lando, D., \& Skødeberg, T. (2002). Analyzing rating transitions and rating drift with continuous observations. Journal of Banking and Finance, 26, 423-444.

Magnus, J., \& Neudecker, H. (1988). Matrix differential calculus with applications in statistics and econometrics. New York: Wiley.

Mandelbrot, B. B., \& Hudson, R. L. (2004). The (mis) behaviour of markets: a fractal view of risk, ruin and reward. London: Profile.

Mora, N. (2006). Guilty beyond reasonable doubt? Journal of Banking and Finance, 30, 2041-2062.

Pesaran, H. H., \& Shin, Y. (1998). Generalized impulse response analysis in linear multivariate models. Economics letters, 58, 17-29.

Reisen, H., \& Maltzan, V. (1999). Boom and bust and sovereign ratings. International Finance, 2, 273-293. 


\section{APPENDIX}

Figure 1- Rating activities of the three credit rating agencies
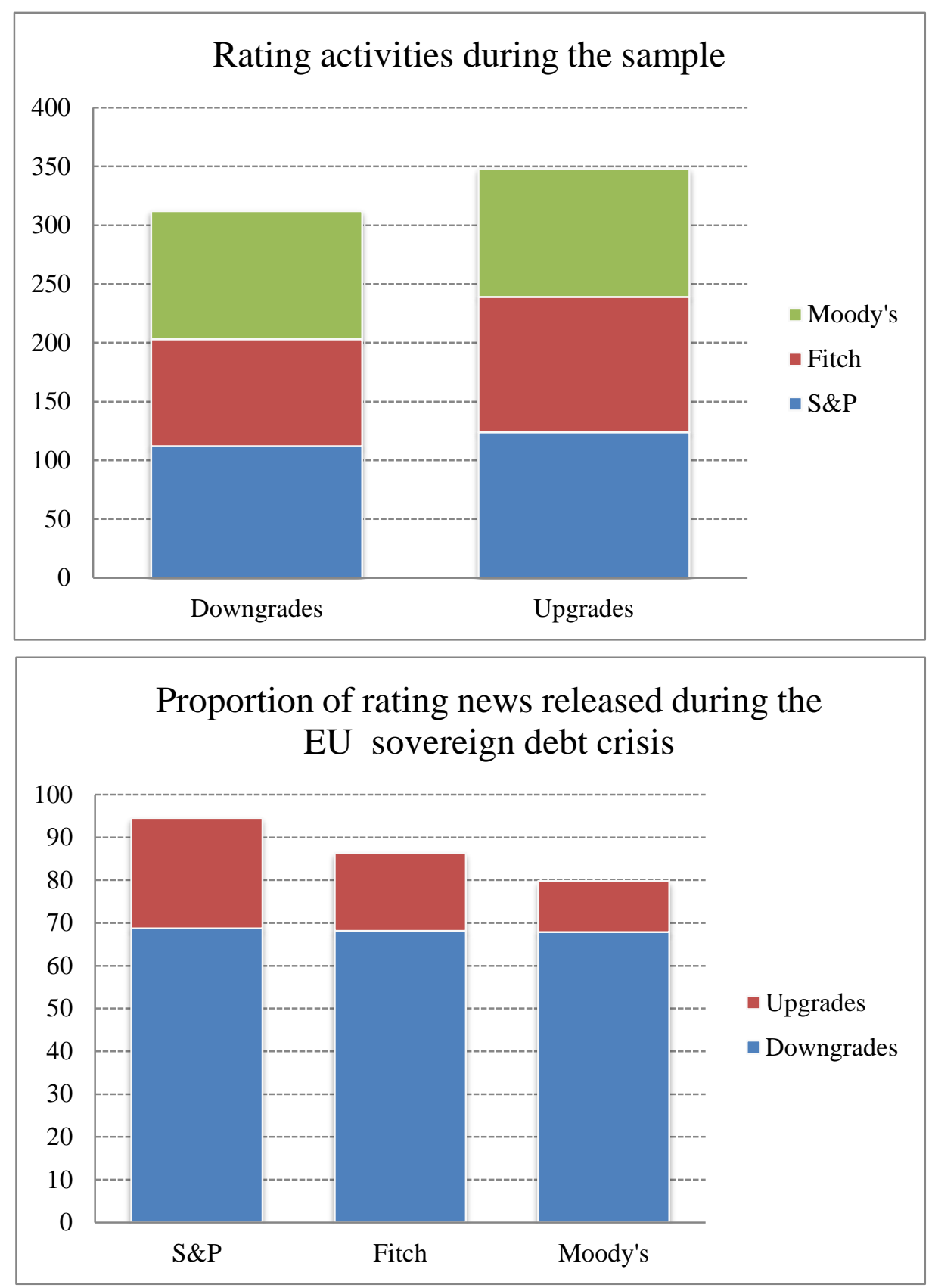

Note: The first chart summarizes the number of rating downgrades and upgrades released by the three credit rating agencies (CRAs), namely Standard and Poors ( S\&P), Fitch and Moody's during our full sample period. The second chart reports the proportion of rating events that the CRAs released during the European sovereign debt crisis beginning from October 2008. 
Figure 2-The European Union sovereign ratings drift
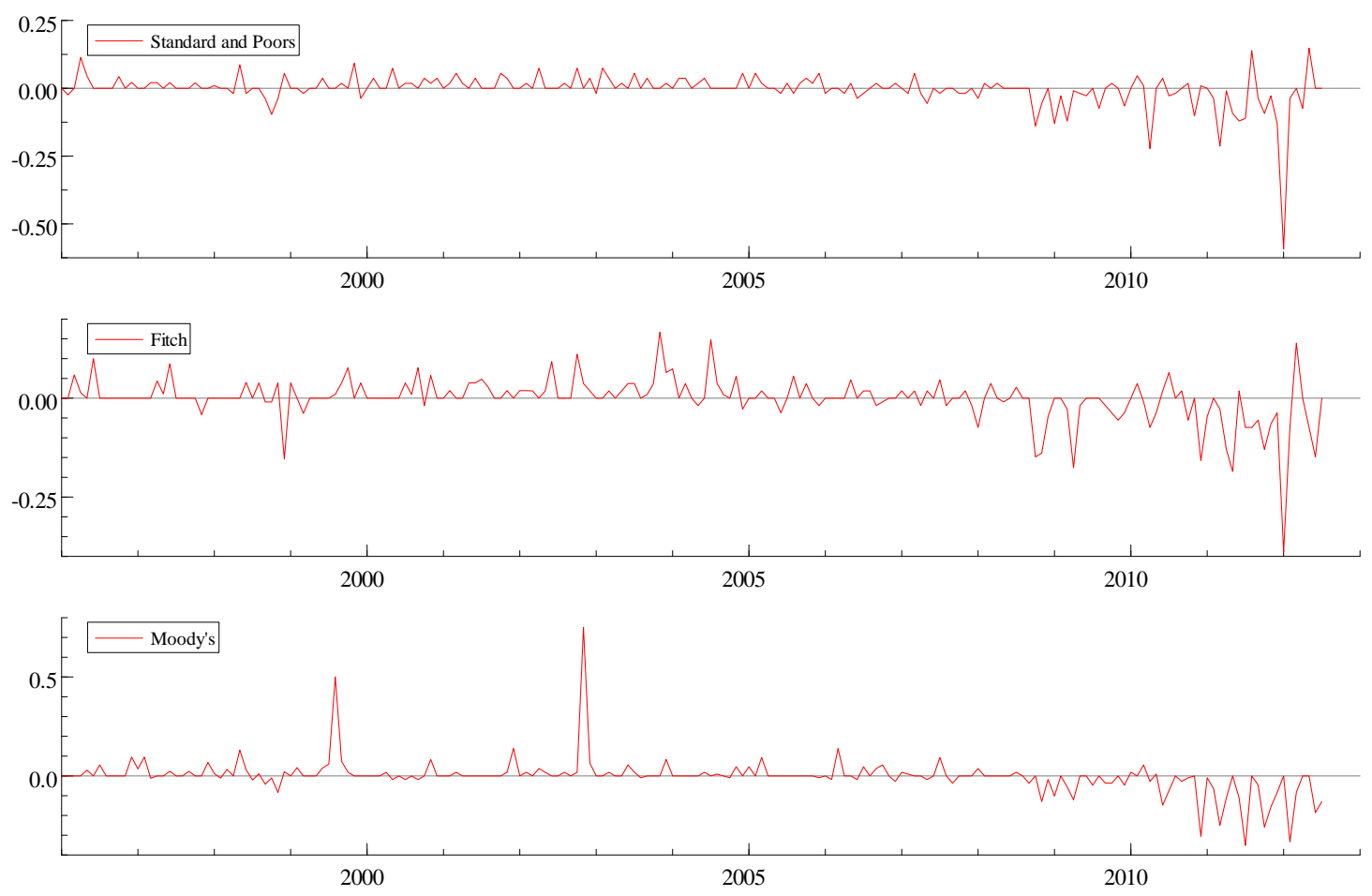

Note: This figure reports the sovereign ratings drifts constructed according to formula (1) from historical long-term foreign currency sovereign credit ratings data for all 27 EU countries covered by Standard and Poor's, Fitch and Moody's.

Figure 3-Sample autocorrelation functions and spectral densities of the realized moments
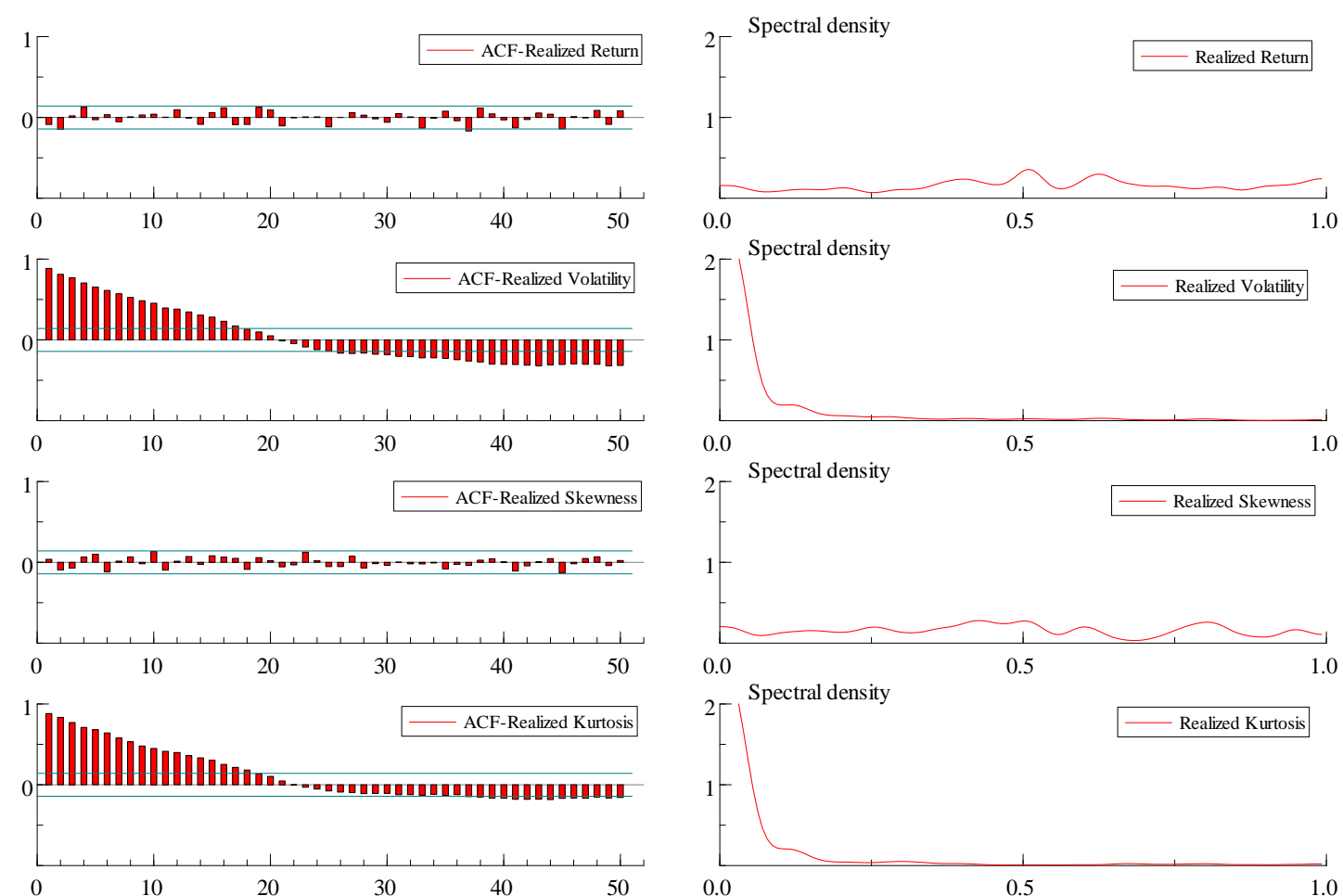

Note: This firgure presents sample autocorrelations and spectral densities of a representative stock market realized return, (logged) realized volatility, realized skewness and (logged) realized kurtosis for a lag of 50 months. 
Figure 4-Average responses of the EU stock realized moments to the sovereign rating drift
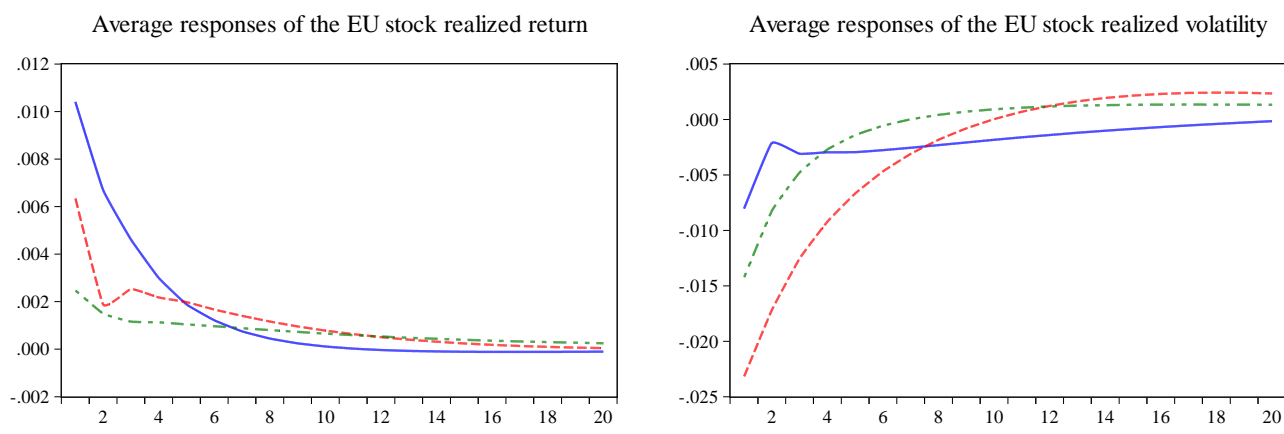

Average responses of the EU stock realized skewness

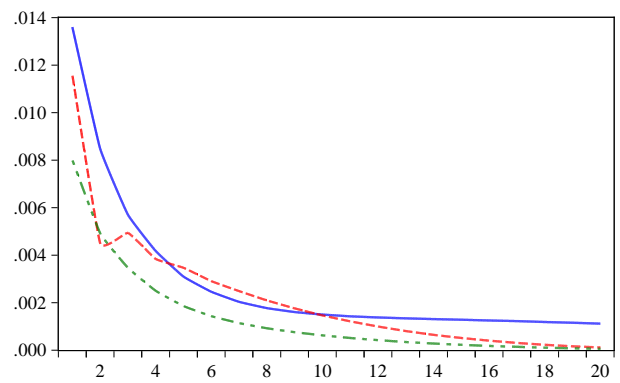

Average responses of the EU stock realized kurtosis

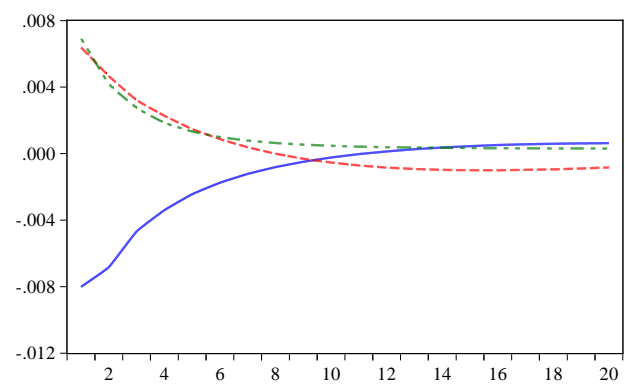

- S\&P --- Fitch --- Moody's

Figure 4a: Average responses of the EU stock realized moments to the shock in upward rating drifts

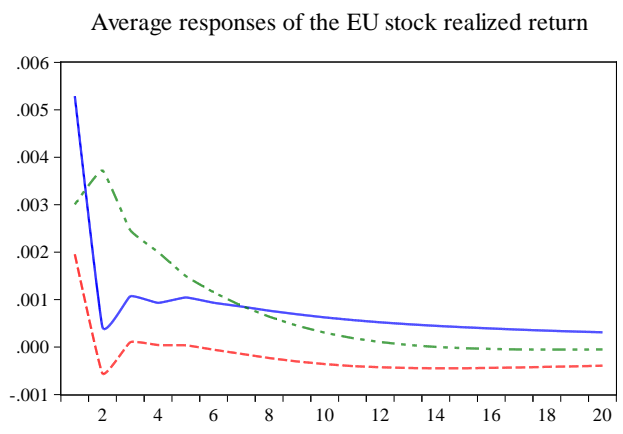

Average responses of the EU stock realized volatility

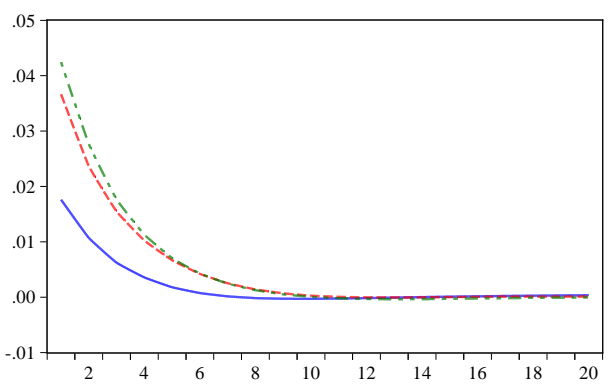

Average responses of the EU stock realized skewness

Average responses of the EU stock realized kurtosis
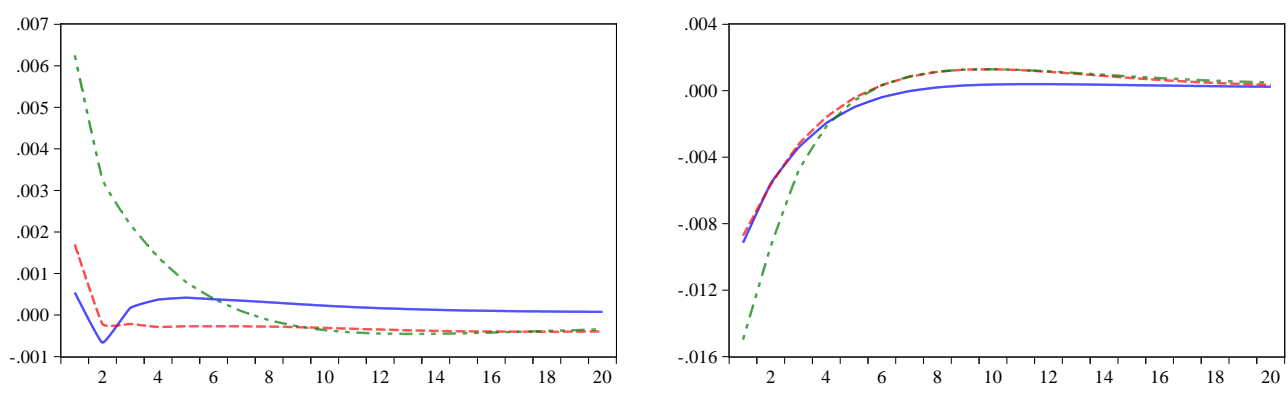

- S\&P --- Fitch -- - Moody's

Figure 4b: Average responses of the EU stock realized moments to the shock in downward rating drift 
Figure 5-Average responses of the EU FX realized moments to the sovereign rating drift
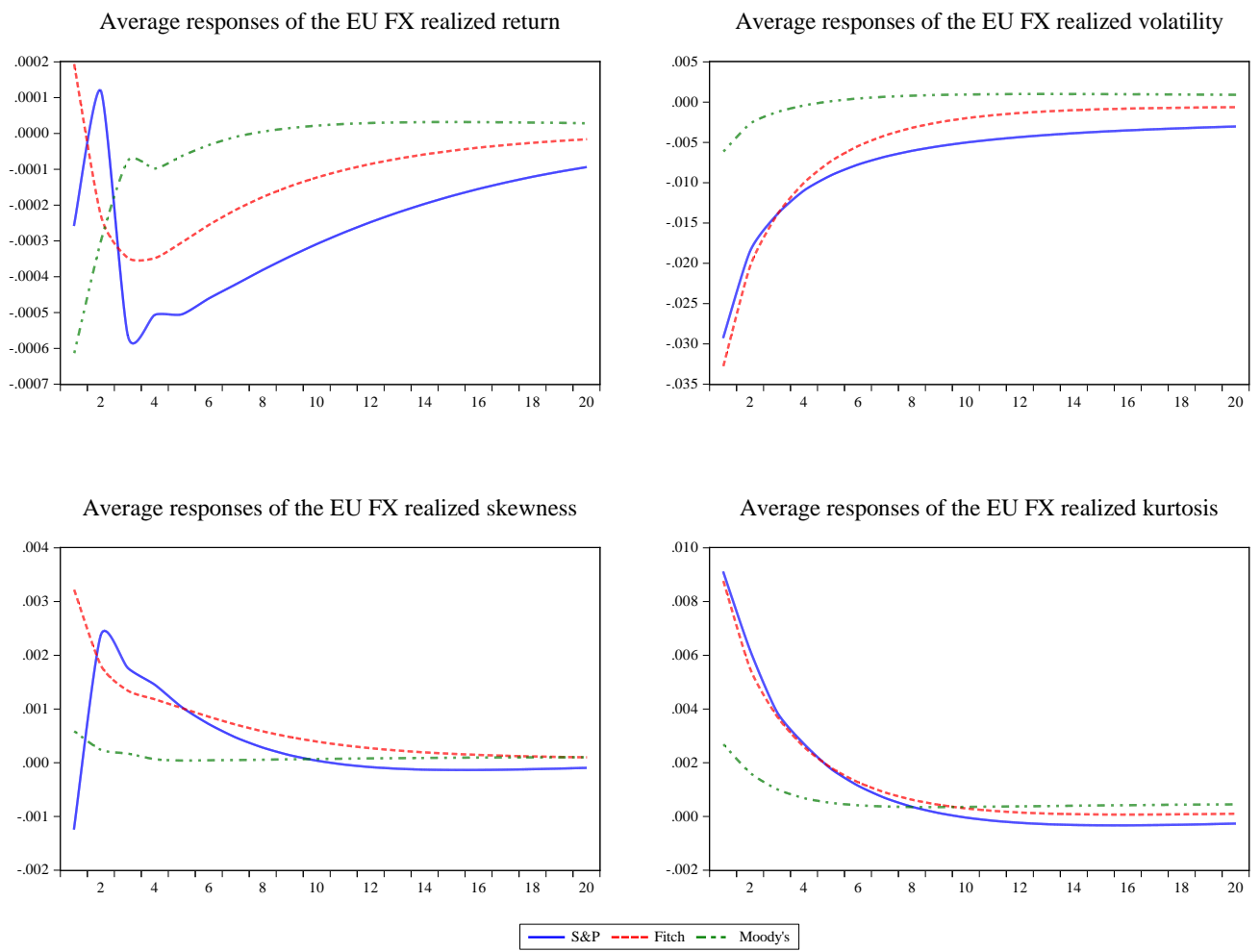

Figure 5a: Average responses of the EU FX realized moments to the shock in upward rating drifts
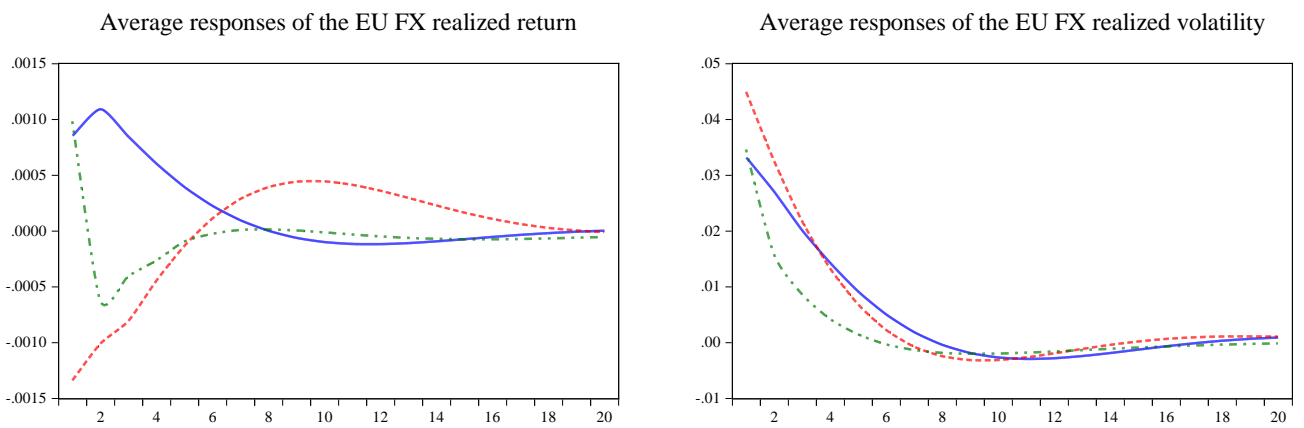

Average responses of the EU FX realized skewness

Average responses of the EU FX realized kurtosis
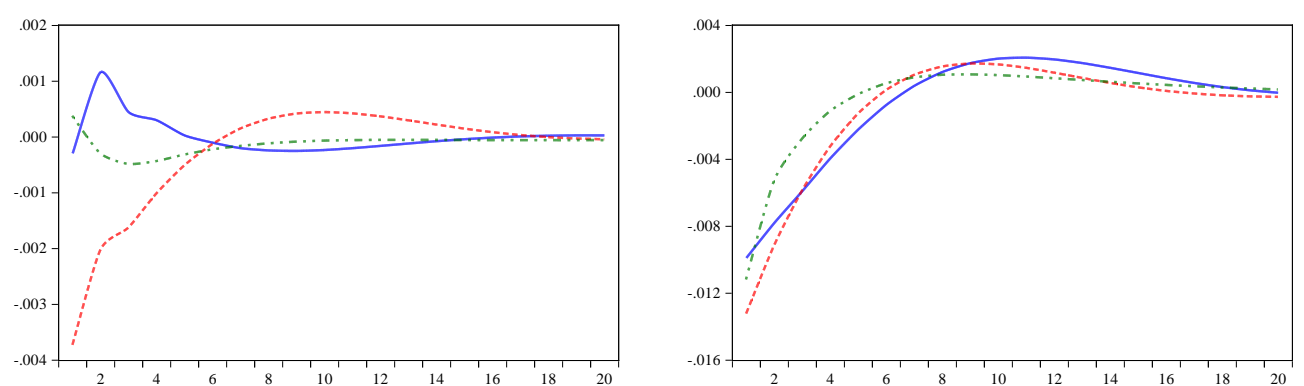

- S\&P ---- Fitch --.- Moody's

Figure 5b: Average responses of the EU FX realized moments to the shock in downward rating drift 
Table 1-Transition probability matrices of sovereign rating drifts

\begin{tabular}{|c|c|c|c|c|c|c|c|c|c|}
\hline \multirow{2}{*}{$\begin{array}{l}\text { Transit } \\
\text { from state }\end{array}$} & \multicolumn{3}{|c|}{ Standard and Poor's } & \multicolumn{3}{|c|}{ Fitch } & \multicolumn{3}{|c|}{ Moody's } \\
\hline & Stable & Upward & Downward & Stable & Upward & Downward & Stable & Upward & Downward \\
\hline Stable & 0.38 & 0.44 & 0.19 & 0.48 & 0.38 & 0.14 & 0.49 & 0.29 & 0.21 \\
\hline Upward & 0.58 & 0.25 & 0.17 & 0.45 & 0.38 & 0.17 & 0.57 & 0.28 & 0.15 \\
\hline Downward & 0.33 & 0.22 & 0.45 & 0.35 & 0.15 & 0.50 & 0.41 & 0.20 & 0.39 \\
\hline
\end{tabular}

Note: This table presents the transition probability matrices of the sovereign rating drifts constructed as in formula (1) from sovereign ratings data provided by Standard and Poors, Fitch and Moody's. The drifts are categorised into three observable states, namely the Stable, Upward and Downward assessments of sovereign credit quality corresponding to zeros, positive and negative values of the sovereign ratings drifts. The reported transition probabilities are the probabilities that the states noted in the rows followed by the states noted in the columns of the table. 
Table 2a-Direct impact of sovereign rating drifts on the EU stock realized return

\begin{tabular}{|c|c|c|c|c|c|c|}
\hline \multirow{2}{*}{ Countries } & \multicolumn{3}{|c|}{ Upward rating drift } & \multicolumn{3}{|c|}{ Downward rating drift } \\
\hline & S\&P & Fitch & Moody's & S\&P & Fitch & Moody's \\
\hline \multirow[t]{2}{*}{ Austria } & -0.483 & -0.445 & 0.066 & -0.009 & -0.367 & -0.188 \\
\hline & $(-0.970)$ & $(-0.747)$ & $(0.354)$ & $(-0.023)$ & $(-0.893)$ & $(-0.679)$ \\
\hline \multirow[t]{2}{*}{ France } & 0.371 & 0.334 & 0.432 & -0.202 & 0.268 & -0.138 \\
\hline & (1.103) & (1.315) & $(3.291)^{* * *}$ & $(-0.768)$ & (0.933) & $(-0.626)$ \\
\hline \multirow[t]{2}{*}{ Germany } & -0.309 & 0.410 & 0.300 & -0.002 & 0.415 & 0.343 \\
\hline & $(-0.640)$ & $(0.881)$ & (1.630) & $(-0.006)$ & (1.325) & (1.593) \\
\hline \multirow[t]{2}{*}{ Greece } & -2.357 & -0.516 & 0.192 & 0.571 & 1.704 & 0.009 \\
\hline & $(-2.342)^{* *}$ & $(-0.651)$ & $(0.765)$ & $(1.292)$ & $(3.889)^{* * *}$ & $(0.020)$ \\
\hline \multirow[t]{2}{*}{ Ireland } & 0.135 & -0.058 & 0.186 & 0.030 & 0.411 & 0.233 \\
\hline & $(0.290)$ & $(-0.141)$ & $(1.386)$ & $(0.134)$ & $(1.446)$ & $(0.906)$ \\
\hline \multirow[t]{2}{*}{ Netherlands } & -0.238 & -0.045 & 0.392 & 0.044 & 0.338 & 0.368 \\
\hline & $(-0.619)$ & $(-0.115)$ & $(2.924)^{* * *}$ & $(0.173)$ & (1.397) & $(2.081)^{* *}$ \\
\hline \multirow[t]{2}{*}{ Spain } & 1.946 & 0.973 & 0.099 & -0.139 & 0.495 & 0.063 \\
\hline & $(4.994)^{* * *}$ & $(2.718)^{* * *}$ & $(0.500)$ & $(-0.377)$ & (1.486) & $(0.276)$ \\
\hline \multirow[t]{2}{*}{ The UK } & -0.492 & -0.139 & -0.047 & -0.526 & 0.041 & 0.462 \\
\hline & $(-1.193)$ & $(-0.525)$ & $(-0.370)$ & $(-2.849)^{* * *}$ & $(0.131)$ & $(2.871)^{* * *}$ \\
\hline \multirow[t]{2}{*}{ Hungary } & -0.704 & -1.020 & 0.096 & 0.343 & 0.261 & -0.042 \\
\hline & $(-1.167)$ & $(-2.494)^{* *}$ & $(0.467)$ & (1.324) & $(0.945)$ & $(-0.147)$ \\
\hline \multirow[t]{2}{*}{ Romania } & -1.084 & 1.116 & 0.132 & 0.512 & -0.016 & -0.099 \\
\hline & $(-1.062)$ & $(1.752)^{*}$ & $(0.356)$ & $(1.298)$ & $(-0.019)$ & $(-0.291)$ \\
\hline
\end{tabular}

Note: This table presents the estimates of the first element of the vector $\nabla^{\left(s_{t}\right)}$ and its associated $t$-statistic (in parentheses). These estimates are interpreted as the impact of upward and downward sovereign ratings drifts on the EU stock realized return as computed in formula (2). The sovereign rating drifts, which represent the assessments of the CRAs on overall EU sovereign credit quality, are constructed as in formula (1) from ratings data provided by Standard and Poor's (S\&P), Fitch and Moody's. *, ** and *** denote significance at the 10, 5 and $1 \%$ levels, respectively. 
Table 2b-Direct impact of sovereign rating drifts on the EU FX realized return

\begin{tabular}{|c|c|c|c|c|c|c|}
\hline \multirow{2}{*}{ Countries } & \multicolumn{3}{|c|}{ Upward rating drift } & \multicolumn{3}{|c|}{ Downward rating drift } \\
\hline & S\&P & Fitch & Moody's & S\&P & Fitch & Moody's \\
\hline Austria & $\begin{array}{c}0.384 \\
(2.967)^{* * *}\end{array}$ & $\begin{array}{l}0.015 \\
(0.096)\end{array}$ & $\begin{array}{l}0.032 \\
(0.444)\end{array}$ & $\begin{array}{l}-0.013 \\
(-0.139)\end{array}$ & $\begin{array}{l}-0.038 \\
(-0.275)\end{array}$ & $\begin{array}{c}0.190 \\
(1.915)^{*}\end{array}$ \\
\hline Belgium & $\begin{array}{c}0.348 \\
(2.619)^{* * *}\end{array}$ & $\begin{array}{l}-0.110 \\
(-0.683)\end{array}$ & $\begin{array}{l}0.101 \\
(1.376)\end{array}$ & $\begin{array}{l}0.018 \\
(0.220)\end{array}$ & $\begin{array}{l}0.174 \\
(1.441)\end{array}$ & $\begin{array}{l}0.086 \\
(0.931)\end{array}$ \\
\hline Bulgaria & $\begin{array}{c}0.808 \\
(3.482)^{* * *}\end{array}$ & $\begin{array}{l}0.249 \\
(1.622)\end{array}$ & $\begin{array}{c}0.285 \\
(2.605)^{* * *}\end{array}$ & $\begin{array}{l}0.056 \\
(0.564)\end{array}$ & $\begin{array}{l}0.050 \\
(0.365)\end{array}$ & $\begin{array}{l}0.118 \\
(1.271)\end{array}$ \\
\hline Cyprus & $\begin{array}{l}0.082 \\
(0.552)\end{array}$ & $\begin{array}{l}-0.017 \\
(-0.105)\end{array}$ & $\begin{array}{l}-0.032 \\
(-0.393)\end{array}$ & $\begin{array}{l}-0.008 \\
(-0.097)\end{array}$ & $\begin{array}{l}-0.007 \\
(-0.062)\end{array}$ & $\begin{array}{c}0.165 \\
(1.846)^{*}\end{array}$ \\
\hline Czech & $\begin{array}{c}0.529 \\
(2.283)^{* *}\end{array}$ & $\begin{array}{l}-0.213 \\
(-0.888)\end{array}$ & $\begin{array}{l}-0.002 \\
(-0.016)\end{array}$ & $\begin{array}{l}0.050 \\
(0.282)\end{array}$ & $\begin{array}{l}0.141 \\
(0.742)\end{array}$ & $\begin{array}{l}0.017 \\
(0.114)\end{array}$ \\
\hline Denmark & $\begin{array}{l}0.342 \\
(1.350)\end{array}$ & $\begin{array}{l}0.024 \\
(0.169)\end{array}$ & $\begin{array}{l}0.048 \\
(0.790)\end{array}$ & $\begin{array}{l}-0.043 \\
(-0.423)\end{array}$ & $\begin{array}{l}-0.053 \\
(-0.413)\end{array}$ & $\begin{array}{c}0.159 \\
(1.804)^{*}\end{array}$ \\
\hline France & $\begin{array}{c}0.427 \\
(3.174)^{* * *}\end{array}$ & $\begin{array}{l}-0.085 \\
(-0.565)\end{array}$ & $\begin{array}{l}0.070 \\
(1.010)\end{array}$ & $\begin{array}{l}0.022 \\
(0.234)\end{array}$ & $\begin{array}{l}0.172 \\
(1.467)\end{array}$ & $\begin{array}{c}0.161 \\
(1.702)^{*}\end{array}$ \\
\hline Germany & $\begin{array}{c}0.361 \\
(2.769)^{* * *}\end{array}$ & $\begin{array}{l}-0.055 \\
(-0.366)\end{array}$ & $\begin{array}{l}0.016 \\
(0.231)\end{array}$ & $\begin{array}{l}0.023 \\
(0.249)\end{array}$ & $\begin{array}{l}0.118 \\
(0.930)\end{array}$ & $\begin{array}{c}0.188 \\
(2.021)^{* *}\end{array}$ \\
\hline Greece & $\begin{array}{c}0.385 \\
(2.645)^{* * *}\end{array}$ & $\begin{array}{l}-0.034 \\
(-0.225)\end{array}$ & $\begin{array}{l}0.066 \\
(0.931)\end{array}$ & $\begin{array}{l}-0.031 \\
(-0.301)\end{array}$ & $\begin{array}{l}0.070 \\
(0.398)\end{array}$ & $\begin{array}{c}0.210 \\
(2.429)^{* *}\end{array}$ \\
\hline Hungary & $\begin{array}{c}0.617 \\
(2.550)^{* *}\end{array}$ & $\begin{array}{c}0.487 \\
(2.408)^{* *}\end{array}$ & $\begin{array}{l}0.061 \\
(0.438)\end{array}$ & $\begin{array}{l}0.138 \\
(0.664)\end{array}$ & $\begin{array}{l}0.150 \\
(0.615)\end{array}$ & $\begin{array}{c}0.396 \\
(2.144)^{* *}\end{array}$ \\
\hline Ireland & $\begin{array}{l}-0.098 \\
(-0.494)\end{array}$ & $\begin{array}{l}-0.137 \\
(-0.726)\end{array}$ & $\begin{array}{l}-0.019 \\
(-0.230)\end{array}$ & $\begin{array}{l}0.092 \\
(1.130)\end{array}$ & $\begin{array}{l}0.091 \\
(0.683)\end{array}$ & $\begin{array}{c}0.181 \\
(1.857)^{*}\end{array}$ \\
\hline Latvia & $\begin{array}{c}0.657 \\
(6.429)^{* * *}\end{array}$ & $\begin{array}{l}-0.030 \\
(-0.232)\end{array}$ & $\begin{array}{l}0.068 \\
(1.332)\end{array}$ & $\begin{array}{l}0.057 \\
(0.569)\end{array}$ & $\begin{array}{l}0.066 \\
(0.451)\end{array}$ & $\begin{array}{l}0.126 \\
(1.489)\end{array}$ \\
\hline Malta & $\begin{array}{l}0.265 \\
(1.633)\end{array}$ & $\begin{array}{l}0.025 \\
(0.120)\end{array}$ & $\begin{array}{c}-0.207 \\
(-2.636)^{* * *}\end{array}$ & $\begin{array}{l}0.105 \\
(0.990)\end{array}$ & $\begin{array}{l}0.079 \\
(0.530)\end{array}$ & $\begin{array}{c}0.272 \\
(2.945)^{* * *}\end{array}$ \\
\hline Netherlands & $\begin{array}{c}0.266 \\
(2.172)^{* *}\end{array}$ & $\begin{array}{l}-0.002 \\
(-0.014)\end{array}$ & $\begin{array}{l}-0.001 \\
(-0.014)\end{array}$ & $\begin{array}{l}0.028 \\
(0.314)\end{array}$ & $\begin{array}{l}-0.063 \\
(-0.467)\end{array}$ & $\begin{array}{l}0.060 \\
(0.560)\end{array}$ \\
\hline Poland & $\begin{array}{c}0.516 \\
(2.315)^{* *}\end{array}$ & $\begin{array}{c}-0.575 \\
(-2.215)^{* *}\end{array}$ & $\begin{array}{l}0.054 \\
(0.434)\end{array}$ & $\begin{array}{l}0.111 \\
(0.491)\end{array}$ & $\begin{array}{l}0.137 \\
(0.500)\end{array}$ & $\begin{array}{l}0.017 \\
(0.082)\end{array}$ \\
\hline Portugal & $\begin{array}{c}0.303 \\
(2.215)^{* *}\end{array}$ & $\begin{array}{l}0.093 \\
(0.595)\end{array}$ & $\begin{array}{c}0.138 \\
(1.978)^{* *}\end{array}$ & $\begin{array}{l}0.076 \\
(0.883)\end{array}$ & $\begin{array}{l}-0.038 \\
(-0.247)\end{array}$ & $\begin{array}{c}0.200 \\
(2.085)^{* *}\end{array}$ \\
\hline Romania & $\begin{array}{c}0.831 \\
(5.035)^{* * *}\end{array}$ & $\begin{array}{l}0.070 \\
(0.310)\end{array}$ & $\begin{array}{l}0.019 \\
(0.163)\end{array}$ & $\begin{array}{l}0.033 \\
(0.257)\end{array}$ & $\begin{array}{c}0.273 \\
(1.767)^{*}\end{array}$ & $\begin{array}{l}0.121 \\
(1.093)\end{array}$ \\
\hline Slovakia & $\begin{array}{c}0.426 \\
(2.284)^{* *}\end{array}$ & $\begin{array}{l}-0.096 \\
(-0.569)\end{array}$ & $\begin{array}{l}0.023 \\
(0.314)\end{array}$ & $\begin{array}{l}0.056 \\
(0.511)\end{array}$ & $\begin{array}{c}0.318 \\
(2.414)^{* *}\end{array}$ & $\begin{array}{l}0.166 \\
(1.368)\end{array}$ \\
\hline Spain & $\begin{array}{c}0.349 \\
(2.270)^{* *}\end{array}$ & $\begin{array}{l}0.089 \\
(0.550)\end{array}$ & $\begin{array}{c}0.155 \\
(2.015)^{* *}\end{array}$ & $\begin{array}{l}0.007 \\
(0.077)\end{array}$ & $\begin{array}{l}0.169 \\
(1.393)\end{array}$ & $\begin{array}{c}0.235 \\
(2.394)^{* *}\end{array}$ \\
\hline Sweden & $\begin{array}{c}0.468 \\
(2.565)^{* * *}\end{array}$ & $\begin{array}{l}0.122 \\
(0.638)\end{array}$ & $\begin{array}{l}0.019 \\
(0.262)\end{array}$ & $\begin{array}{l}0.018 \\
(0.151)\end{array}$ & $\begin{array}{l}0.101 \\
(0.690)\end{array}$ & $\begin{array}{l}0.045 \\
(0.321)\end{array}$ \\
\hline UK & $\begin{array}{c}0.260 \\
(2.029)^{* *}\end{array}$ & $\begin{array}{l}-0.001 \\
(-0.006)\end{array}$ & $\begin{array}{l}-0.012 \\
(-0.214)\end{array}$ & $\begin{array}{l}-0.006 \\
(-0.066)\end{array}$ & $\begin{array}{l}0.008 \\
(0.076)\end{array}$ & $\begin{array}{l}-0.011 \\
(-0.138)\end{array}$ \\
\hline
\end{tabular}

Note: This table presents the estimates of the first element of the vector $\nabla^{\left(s_{t}\right)}$ and its associated $t$-statistic (in parentheses). These estimates are interpreted as the impact of upward and downward sovereign rating drifts on the EU FX realized return as computed in formula (2). The sovereign ratings drifts, which represent the assessments of the CRAs on overall EU sovereign credit quality, are constructed as in formula (1) from ratings data provided by Standard and Poor's (S\&P), Fitch and Moody’s. *, ** and *** denote significance at the 10,5 and $1 \%$ levels, respectively. 
Table 3a-Direct impact of sovereign rating drifts on the EU stock realized volatility

\begin{tabular}{|c|c|c|c|c|c|c|}
\hline \multirow{2}{*}{ Countries } & \multicolumn{3}{|c|}{ Upward rating drift } & \multicolumn{3}{|c|}{ Downward rating drift } \\
\hline & S\&P & Fitch & Moody's & S\&P & Fitch & Moody's \\
\hline \multirow[t]{2}{*}{ Austria } & -1.120 & -1.152 & -0.430 & 0.379 & 1.234 & 1.071 \\
\hline & $(-1.214)$ & $(-1.188)$ & $(-1.857)^{*}$ & $(1.611)$ & $(7.442)^{* * *}$ & $(6.860)^{* * *}$ \\
\hline \multirow[t]{2}{*}{ France } & 0.945 & 0.165 & -0.255 & 0.860 & 0.969 & 0.711 \\
\hline & $(1.740)^{*}$ & $(0.210)$ & $(-0.636)$ & $(3.191)^{* * *}$ & $(3.224)^{* * *}$ & $(3.479)^{* * *}$ \\
\hline \multirow[t]{2}{*}{ Germany } & 0.783 & 0.378 & 0.053 & 0.737 & 0.356 & -0.121 \\
\hline & $(1.165)$ & $(0.731)$ & $(0.150)$ & $(2.124)^{* *}$ & $(0.986)$ & $(-0.320)$ \\
\hline \multirow[t]{2}{*}{ Greece } & 1.508 & -0.912 & -0.506 & 0.757 & 2.242 & 1.498 \\
\hline & $(1.427)$ & $(-1.072)$ & $(-1.290)$ & $(2.473)^{* *}$ & $(6.465)^{* * *}$ & $(6.154)^{* * *}$ \\
\hline \multirow[t]{2}{*}{ Ireland } & -0.233 & -1.440 & -0.138 & 0.134 & 0.394 & 0.592 \\
\hline & $(-0.273)$ & $(-3.001)^{* * *}$ & $(-0.457)$ & $(0.345)$ & $(1.411)$ & $(2.263)^{* *}$ \\
\hline \multirow[t]{2}{*}{ Netherlands } & 1.525 & 0.076 & -0.224 & 0.550 & 0.798 & -0.228 \\
\hline & $(2.228)^{* *}$ & $(0.089)$ & $(-0.988)$ & (1.602) & $(1.920)^{*}$ & $(-0.926)$ \\
\hline \multirow[t]{2}{*}{ Spain } & 2.640 & -0.667 & -0.262 & 0.834 & 2.054 & 0.637 \\
\hline & $(1.901)^{*}$ & $(-0.690)$ & $(-0.581)$ & (1.225) & $(2.609)^{* * *}$ & $(1.343)$ \\
\hline \multirow[t]{2}{*}{ The UK } & -0.158 & -0.636 & -0.421 & 0.389 & 0.733 & 0.598 \\
\hline & $(-0.122)$ & $(-0.973)$ & $(-2.037)^{* *}$ & (1.692)* & (1.929)* & $(2.383)^{* *}$ \\
\hline \multirow[t]{2}{*}{ Hungary } & 0.842 & -0.993 & -0.277 & 0.203 & 1.534 & 0.696 \\
\hline & $(0.948)$ & $(-1.382)$ & $(-0.782)$ & $(0.469)$ & $(4.131)^{* * *}$ & $(1.774)^{*}$ \\
\hline \multirow[t]{2}{*}{ Romania } & -0.443 & -2.193 & -0.077 & -0.414 & 0.523 & 0.091 \\
\hline & $(-0.531)$ & $(-2.821)^{* * *}$ & $(-0.187)$ & $(-1.549)$ & (1.178) & $(0.211)$ \\
\hline
\end{tabular}

Note: This table presents the estimates of the second element of the vector $\nabla^{\left(s_{t}\right)}$ and its associated $t$-statistic (in parentheses). These estimates are interpreted as the impact of upward and downward sovereign ratings drifts on realized stock market volatility as computed in formula (3). The sovereign ratings drifts, which represent the assessments of the CRAs on overall EU sovereign credit quality, are constructed as in formula (1) from ratings data provided by Standard and Poor's (S\&P), Fitch and Moody's. *, ** and *** denote significance at the 10,5 and $1 \%$ levels, respectively. 
Table 3b-Direct impact of sovereign rating drifts on the EU FX realized volatility

\begin{tabular}{|c|c|c|c|c|c|c|}
\hline \multirow{2}{*}{ Countries } & \multicolumn{3}{|c|}{ Upward rating drift } & \multicolumn{3}{|c|}{ Downward rating drift } \\
\hline & S\&P & Fitch & Moody's & S\&P & Fitch & Moody's \\
\hline Austria & $\begin{array}{l}-0.799 \\
(-1.207)\end{array}$ & $\begin{array}{c}-1.140 \\
(-2.406)^{* *}\end{array}$ & $\begin{array}{l}-0.082 \\
(-0.337)\end{array}$ & $\begin{array}{c}0.679 \\
(2.895)^{* * *}\end{array}$ & $\begin{array}{c}1.599 \\
(5.294)^{* * *}\end{array}$ & $\begin{array}{c}0.774 \\
(2.949)^{* * *}\end{array}$ \\
\hline Belgium & $\begin{array}{l}-0.768 \\
(-1.228)\end{array}$ & $\begin{array}{c}-1.410 \\
(-3.015)^{* * *}\end{array}$ & $\begin{array}{l}-0.132 \\
(-0.514)\end{array}$ & $\begin{array}{c}0.871 \\
(3.471)^{* * *}\end{array}$ & $\begin{array}{c}1.430 \\
(4.359)^{* * *}\end{array}$ & $\begin{array}{c}1.364 \\
(4.804)^{* * *}\end{array}$ \\
\hline Bulgaria & $\begin{array}{l}-0.374 \\
(-0.470)\end{array}$ & $\begin{array}{l}-1.014 \\
(-1.213)\end{array}$ & $\begin{array}{l}-0.044 \\
(-0.120)\end{array}$ & $\begin{array}{l}0.263 \\
(0.608)\end{array}$ & $\begin{array}{l}0.590 \\
(1.317)\end{array}$ & $\begin{array}{l}0.314 \\
(0.708)\end{array}$ \\
\hline Cyprus & $\begin{array}{l}-0.532 \\
(-1.129)\end{array}$ & $\begin{array}{c}-0.828 \\
(-1.889)^{*}\end{array}$ & $\begin{array}{l}-0.126 \\
(-0.629)\end{array}$ & $\begin{array}{l}0.038 \\
(0.144)\end{array}$ & $\begin{array}{c}0.764 \\
(2.247)^{* *}\end{array}$ & $\begin{array}{l}0.457 \\
(1.302)\end{array}$ \\
\hline Czech & $\begin{array}{c}-1.969 \\
(-2.814)^{* * *}\end{array}$ & $\begin{array}{l}-0.285 \\
(-0.456)\end{array}$ & $\begin{array}{l}-0.413 \\
(-1.532)\end{array}$ & $\begin{array}{c}0.711 \\
(2.728)^{* * *}\end{array}$ & $\begin{array}{c}0.719 \\
(3.596)^{* * *}\end{array}$ & $\begin{array}{c}0.476 \\
(2.270)^{* *}\end{array}$ \\
\hline Denmark & $\begin{array}{l}-0.630 \\
(-1.501)\end{array}$ & $\begin{array}{c}-1.143 \\
(-2.253)^{* *}\end{array}$ & $\begin{array}{l}0.048 \\
(0.179)\end{array}$ & $\begin{array}{c}0.590 \\
(3.148)^{* * *}\end{array}$ & $\begin{array}{c}0.672 \\
(3.113)^{* * *}\end{array}$ & $\begin{array}{c}0.896 \\
(4.089)^{* * *}\end{array}$ \\
\hline France & $\begin{array}{l}-0.719 \\
(-1.113)\end{array}$ & $\begin{array}{c}-1.286 \\
(-2.683)^{* * *}\end{array}$ & $\begin{array}{l}-0.135 \\
(-0.514)\end{array}$ & $\begin{array}{c}0.774 \\
(2.924)^{* * *}\end{array}$ & $\begin{array}{c}1.401 \\
(4.467)^{* * *}\end{array}$ & $\begin{array}{c}0.544 \\
(1.849)^{*}\end{array}$ \\
\hline Germany & $\begin{array}{l}-0.752 \\
(-1.213)\end{array}$ & $\begin{array}{c}-1.665 \\
(-3.457)^{* * *}\end{array}$ & $\begin{array}{l}-0.171 \\
(-0.817)\end{array}$ & $\begin{array}{c}0.671 \\
(2.842)^{* * *}\end{array}$ & $\begin{array}{c}1.455 \\
(5.970)^{* * *}\end{array}$ & $\begin{array}{c}0.738 \\
(2.961)^{* * *}\end{array}$ \\
\hline Greece & $\begin{array}{l}-0.498 \\
(-0.755)\end{array}$ & $\begin{array}{c}-1.295 \\
(-2.621)^{* * *}\end{array}$ & $\begin{array}{l}0.048 \\
(0.177)\end{array}$ & $\begin{array}{c}0.952 \\
(3.728)^{* * *}\end{array}$ & $\begin{array}{c}1.970 \\
(6.624)^{* * *}\end{array}$ & $\begin{array}{c}1.057 \\
(3.615)^{* * *}\end{array}$ \\
\hline Hungary & $\begin{array}{c}-1.586 \\
(-2.424)^{* *}\end{array}$ & $\begin{array}{l}-1.006 \\
(-1.497)\end{array}$ & $\begin{array}{l}-0.026 \\
(-0.105)\end{array}$ & $\begin{array}{c}0.553 \\
(1.854)^{*}\end{array}$ & $\begin{array}{c}1.227 \\
(4.066)^{* * *}\end{array}$ & $\begin{array}{l}0.535 \\
(1.466)\end{array}$ \\
\hline Ireland & $\begin{array}{l}-0.883 \\
(-1.366)\end{array}$ & $\begin{array}{c}-0.971 \\
(-2.017)^{* *}\end{array}$ & $\begin{array}{l}0.023 \\
(0.085)\end{array}$ & $\begin{array}{c}0.932 \\
(4.033)^{* * *}\end{array}$ & $\begin{array}{c}1.826 \\
(6.375)^{* * *}\end{array}$ & $\begin{array}{l}0.461 \\
(1.493)\end{array}$ \\
\hline Latvia & $\begin{array}{c}-1.916 \\
(-2.667)^{* * *}\end{array}$ & $\begin{array}{l}-0.131 \\
(-0.194)\end{array}$ & $\begin{array}{l}-0.060 \\
(-0.186)\end{array}$ & $\begin{array}{c}0.670 \\
(1.845)^{*}\end{array}$ & $\begin{array}{c}0.871 \\
(2.288)^{* *}\end{array}$ & $\begin{array}{l}0.615 \\
(1.421)\end{array}$ \\
\hline Malta & $\begin{array}{l}-1.857 \\
(-1.456)\end{array}$ & $\begin{array}{c}-2.402 \\
(-2.708)^{* * *}\end{array}$ & $\begin{array}{l}0.178 \\
(0.448)\end{array}$ & $\begin{array}{c}0.677 \\
(1.723)^{*}\end{array}$ & $\begin{array}{c}0.942 \\
(2.296)^{* *}\end{array}$ & $\begin{array}{c}0.766 \\
(2.315)^{* *}\end{array}$ \\
\hline Netherlands & $\begin{array}{l}-0.868 \\
(-1.401)\end{array}$ & $\begin{array}{c}-1.604 \\
(-3.288)^{* * *}\end{array}$ & $\begin{array}{l}-0.187 \\
(-0.777)\end{array}$ & $\begin{array}{c}0.592 \\
(2.305)^{* *}\end{array}$ & $\begin{array}{c}1.554 \\
(5.421)^{* * *}\end{array}$ & $\begin{array}{c}1.470 \\
(5.268)^{* * *}\end{array}$ \\
\hline Poland & $\begin{array}{l}-0.181 \\
(-0.200)\end{array}$ & $\begin{array}{l}-1.175 \\
(-1.552)\end{array}$ & $\begin{array}{l}0.072 \\
(0.180)\end{array}$ & $\begin{array}{c}0.679 \\
(2.035)^{* *}\end{array}$ & $\begin{array}{c}1.461 \\
(3.187)^{* * *}\end{array}$ & $\begin{array}{l}0.598 \\
(1.624)\end{array}$ \\
\hline Portugal & $\begin{array}{l}-0.807 \\
(-1.255)\end{array}$ & $\begin{array}{c}-1.107 \\
(-1.954)^{*}\end{array}$ & $\begin{array}{l}-0.145 \\
(-0.513)\end{array}$ & $\begin{array}{c}0.612 \\
(2.056)^{* *}\end{array}$ & $\begin{array}{c}2.195 \\
(7.594)^{* * *}\end{array}$ & $\begin{array}{c}0.965 \\
(3.413)^{* * *}\end{array}$ \\
\hline Romania & $\begin{array}{l}0.325 \\
(0.230)\end{array}$ & $\begin{array}{l}0.081 \\
(0.065)\end{array}$ & $\begin{array}{l}-0.232 \\
(-0.425)\end{array}$ & $\begin{array}{l}0.327 \\
(0.600)\end{array}$ & $\begin{array}{c}1.994 \\
(3.318)^{* * *}\end{array}$ & $\begin{array}{l}-0.427 \\
(-0.804)\end{array}$ \\
\hline Slovakia & $\begin{array}{c}-2.038 \\
(-3.361)^{* * *}\end{array}$ & $\begin{array}{l}-0.953 \\
(-1.621)\end{array}$ & $\begin{array}{l}-0.079 \\
(-0.274)\end{array}$ & $\begin{array}{c}0.633 \\
(2.056)^{* *}\end{array}$ & $\begin{array}{c}1.001 \\
(4.268)^{* * *}\end{array}$ & $\begin{array}{l}0.378 \\
(0.890)\end{array}$ \\
\hline Spain & $\begin{array}{l}-0.843 \\
(-1.223)\end{array}$ & $\begin{array}{c}-1.164 \\
(-2.085)^{* *}\end{array}$ & $\begin{array}{l}-0.113 \\
(-0.421)\end{array}$ & $\begin{array}{c}0.945 \\
(3.843)^{* * *}\end{array}$ & $\begin{array}{c}1.333 \\
(3.888)^{* * *}\end{array}$ & $\begin{array}{c}0.986 \\
(3.294)^{* * *}\end{array}$ \\
\hline Sweden & $\begin{array}{l}-0.188 \\
(-0.373)\end{array}$ & $\begin{array}{c}-0.746 \\
(-1.864)^{*}\end{array}$ & $\begin{array}{l}-0.165 \\
(-0.850)\end{array}$ & $\begin{array}{c}0.359 \\
(1.961)^{* *}\end{array}$ & $\begin{array}{c}0.848 \\
(3.397)^{* * *}\end{array}$ & $\begin{array}{c}0.426 \\
(2.051)^{* * *}\end{array}$ \\
\hline UK & $\begin{array}{c}-1.216 \\
(-2.415)^{* *}\end{array}$ & $\begin{array}{c}-1.785 \\
(-3.541)^{* * *}\end{array}$ & $\begin{array}{l}-0.159 \\
(-0.686)\end{array}$ & $\begin{array}{l}0.128 \\
(0.546)\end{array}$ & $\begin{array}{c}0.574 \\
(2.299)^{* * *}\end{array}$ & $\begin{array}{l}0.240 \\
(1.149)\end{array}$ \\
\hline
\end{tabular}

Note: This table presents the estimates of the second element of the vector $\nabla^{\left(s_{t}\right)}$ and its associated $t$-statistic (in parentheses). These estimates are interpreted as the impact of upward and downward sovereign rating drifts on the EU FX realized volatility as computed in formula (3). The sovereign rating drifts, which represent the assessments of the CRAs on overall EU sovereign credit quality, are constructed as in formula (1) from ratings data provided by Standard and Poor's (S\&P), Fitch and Moody's. *, ** and *** denote significance at the 10,5 and $1 \%$ levels, respectively. 


\begin{tabular}{|c|c|c|c|c|c|c|}
\hline \multirow{2}{*}{ Countries } & \multicolumn{3}{|c|}{ Upward rating drift } & \multicolumn{3}{|c|}{ Downward rating drift } \\
\hline & S\&P & Fitch & Moody's & S\&P & Fitch & Moody's \\
\hline \multirow[t]{2}{*}{ Austria } & 1.089 & -0.620 & -0.021 & 0.027 & 0.148 & -0.213 \\
\hline & $(3.453)^{* * *}$ & $(-0.784)$ & $(-0.103)$ & $(0.116)$ & $(0.556)$ & $(-0.974)$ \\
\hline \multirow[t]{2}{*}{ France } & 0.557 & -0.033 & 0.248 & -0.065 & 0.027 & -0.009 \\
\hline & $(1.225)$ & $(-0.108)$ & $(1.970)^{* *}$ & $(-0.319)$ & $(0.134)$ & $(-0.066)$ \\
\hline \multirow[t]{2}{*}{ Germany } & 0.307 & -0.321 & 0.105 & 0.146 & 0.487 & 0.329 \\
\hline & (1.069) & $(-0.974)$ & $(0.669)$ & $(0.510)$ & $(3.082)^{* * *}$ & $(2.135)^{* *}$ \\
\hline \multirow[t]{2}{*}{ Greece } & -0.034 & 1.503 & 0.698 & 0.051 & 0.898 & -0.194 \\
\hline & $(-0.035)$ & $(2.641)^{* * *}$ & $(3.159)^{* * *}$ & $(0.154)$ & $(3.308)^{* * *}$ & $(-0.482)$ \\
\hline \multirow[t]{2}{*}{ Ireland } & 0.834 & 1.019 & -0.007 & 0.333 & 0.700 & 0.202 \\
\hline & (1.699)* & $(2.693)^{* * *}$ & $(-0.038)$ & (1.884)* & $(3.849)^{* * *}$ & $(0.966)$ \\
\hline \multirow[t]{2}{*}{ Netherlands } & 0.950 & -0.411 & 0.307 & 0.109 & 0.302 & 0.290 \\
\hline & $(2.832)^{* * *}$ & $(-0.985)$ & $(2.089)^{* *}$ & $(0.595)$ & $(1.715)^{*}$ & $(2.115)^{* *}$ \\
\hline \multirow[t]{2}{*}{ Spain } & 3.790 & 0.839 & 0.019 & -0.094 & 0.456 & 0.585 \\
\hline & $(7.638)^{* * *}$ & (1.353) & $(0.087)$ & $(-0.252)$ & $(1.650)^{*}$ & $(2.731)^{* * *}$ \\
\hline \multirow[t]{2}{*}{ The UK } & -0.446 & -1.312 & -0.178 & -0.296 & -0.064 & 0.466 \\
\hline & $(-0.724)$ & $(-2.199)^{* *}$ & $(-0.829)$ & $(-1.916)^{*}$ & $(-0.304)$ & $(2.951)^{* * *}$ \\
\hline \multirow[t]{2}{*}{ Hungary } & 0.622 & 0.719 & 0.216 & 0.223 & 0.115 & -0.124 \\
\hline & $(1.645)^{*}$ & $(2.613)^{* * *}$ & $(1.258)$ & $(1.249)$ & $(0.743)$ & $(-0.573)$ \\
\hline \multirow[t]{2}{*}{ Romania } & -1.836 & 0.933 & 0.252 & 0.792 & 0.805 & 0.292 \\
\hline & $(-1.878)^{*}$ & (1.541) & $(0.730)$ & $(2.271)^{* *}$ & $(2.567)^{* *}$ & $(0.741)$ \\
\hline
\end{tabular}

Note: This table presents the estimates of the third element of the vector $\nabla^{\left(s_{t}\right)}$ and its associated $t$-statistic (in parentheses). These estimates are interpreted as the impact of upward and downward sovereign rating drifts on the EU stock realized skewness as computed in formula (4). The sovereign ratings drifts, which represent the assessments of the CRAs on overall EU sovereign credit quality, are constructed as in formula (1) from ratings data provided by Standard and Poor's (S\&P), Fitch and Moody's. *,** and *** denote significance at the 10, 5 and 1\% levels, respectively. 
Table 4b-Direct impact of sovereign rating drifts on the EU FX realized skewness

\begin{tabular}{|c|c|c|c|c|c|c|}
\hline \multirow{2}{*}{ Countries } & \multicolumn{3}{|c|}{ Upward rating drift } & \multicolumn{3}{|c|}{ Downward rating drift } \\
\hline & S\&P & Fitch & Moody's & S\&P & Fitch & Moody's \\
\hline Austria & $\begin{array}{c}0.481 \\
(1.915)^{*}\end{array}$ & $\begin{array}{c}0.392 \\
(1.811)^{*}\end{array}$ & $\begin{array}{c}0.286 \\
(2.754)^{* * *}\end{array}$ & $\begin{array}{l}0.154 \\
(1.585)\end{array}$ & $\begin{array}{c}0.226 \\
(1.884)^{*}\end{array}$ & $\begin{array}{l}0.028 \\
(0.230)\end{array}$ \\
\hline Belgium & $\begin{array}{l}0.371 \\
(1.576)\end{array}$ & $\begin{array}{c}0.502 \\
(2.392)^{* *}\end{array}$ & $\begin{array}{c}0.291 \\
(2.962)^{* * *}\end{array}$ & $\begin{array}{c}0.225 \\
(2.723)^{* * *}\end{array}$ & $\begin{array}{c}0.386 \\
(3.366)^{* * *}\end{array}$ & $\begin{array}{l}0.035 \\
(0.371)\end{array}$ \\
\hline Bulgaria & $\begin{array}{c}0.508 \\
(1.746)^{*}\end{array}$ & $\begin{array}{c}0.837 \\
(3.729)^{* * *}\end{array}$ & $\begin{array}{c}0.407 \\
(2.824) * * *\end{array}$ & $\begin{array}{c}0.184 \\
(1.670)^{*}\end{array}$ & $\begin{array}{l}0.162 \\
(1.284)\end{array}$ & $\begin{array}{l}0.055 \\
(0.625)\end{array}$ \\
\hline Cyprus & $\begin{array}{l}0.050 \\
(0.191)\end{array}$ & $\begin{array}{l}-0.353 \\
(-1.201)\end{array}$ & $\begin{array}{l}-0.135 \\
(-1.319)\end{array}$ & $\begin{array}{c}0.167 \\
(1.951)^{*}\end{array}$ & $\begin{array}{c}0.228 \\
(2.026)^{* *}\end{array}$ & $\begin{array}{l}0.099 \\
(1.054)\end{array}$ \\
\hline Czech & $\begin{array}{l}-0.060 \\
(-0.158)\end{array}$ & $\begin{array}{l}-0.181 \\
(-0.598)\end{array}$ & $\begin{array}{c}0.330 \\
(2.929)^{* * *}\end{array}$ & $\begin{array}{l}0.132 \\
(0.984)\end{array}$ & $\begin{array}{l}0.165 \\
(1.270)\end{array}$ & $\begin{array}{c}0.188 \\
(2.093)^{* *}\end{array}$ \\
\hline Denmark & $\begin{array}{l}0.184 \\
(0.107)\end{array}$ & $\begin{array}{l}0.257 \\
(1.310)\end{array}$ & $\begin{array}{l}0.089 \\
(0.979)\end{array}$ & $\begin{array}{l}0.057 \\
(0.479)\end{array}$ & $\begin{array}{c}0.230 \\
(2.136)^{* *}\end{array}$ & $\begin{array}{c}0.269 \\
(2.833)^{* * *}\end{array}$ \\
\hline France & $\begin{array}{c}0.418 \\
(1.685)^{*}\end{array}$ & $\begin{array}{c}0.467 \\
(2.323)^{* *}\end{array}$ & $\begin{array}{c}0.332 \\
(3.530)^{* * *}\end{array}$ & $\begin{array}{c}0.211 \\
(2.318)^{* *}\end{array}$ & $\begin{array}{c}0.336 \\
(2.857)^{* * *}\end{array}$ & $\begin{array}{l}0.050 \\
(0.501)\end{array}$ \\
\hline Germany & $\begin{array}{l}0.320 \\
(1.350)\end{array}$ & $\begin{array}{c}0.416 \\
(2.150)^{* *}\end{array}$ & $\begin{array}{c}0.185 \\
(1.797)^{*}\end{array}$ & $\begin{array}{c}0.189 \\
(2.021)^{* *}\end{array}$ & $\begin{array}{c}0.262 \\
(2.302)^{* *}\end{array}$ & $\begin{array}{l}0.065 \\
(0.625)\end{array}$ \\
\hline Greece & $\begin{array}{l}0.264 \\
(1.273)\end{array}$ & $\begin{array}{l}0.262 \\
(1.300)\end{array}$ & $\begin{array}{c}0.262 \\
(2.633)^{* * *}\end{array}$ & $\begin{array}{c}0.180 \\
(1.817)^{*}\end{array}$ & $\begin{array}{l}0.206 \\
(1.566)\end{array}$ & $\begin{array}{l}0.137 \\
(1.592)\end{array}$ \\
\hline Hungary & $\begin{array}{l}-0.551 \\
(-1.453)\end{array}$ & $\begin{array}{c}0.563 \\
(2.267)^{* *}\end{array}$ & $\begin{array}{l}-0.015 \\
(-0.101)\end{array}$ & $\begin{array}{l}0.051 \\
(0.351)\end{array}$ & $\begin{array}{l}-0.228 \\
(-1.034)\end{array}$ & $\begin{array}{l}-0.085 \\
(-0.605)\end{array}$ \\
\hline Ireland & $\begin{array}{l}-0.335 \\
(-1.070)\end{array}$ & $\begin{array}{l}-0.254 \\
(-1.074)\end{array}$ & $\begin{array}{l}0.012 \\
(0.112)\end{array}$ & $\begin{array}{c}0.254 \\
(3.293)^{* * *}\end{array}$ & $\begin{array}{c}0.254 \\
(2.099)^{* *}\end{array}$ & $\begin{array}{l}0.138 \\
(1.468)\end{array}$ \\
\hline Latvia & $\begin{array}{c}0.637 \\
(4.068)^{* * *}\end{array}$ & $\begin{array}{c}0.323 \\
(2.561)^{* *}\end{array}$ & $\begin{array}{l}-0.045 \\
(-0.529)\end{array}$ & $\begin{array}{l}0.053 \\
(0.821)\end{array}$ & $\begin{array}{l}0.108 \\
(1.024)\end{array}$ & $\begin{array}{c}0.144 \\
(2.344)^{* *}\end{array}$ \\
\hline Malta & $\begin{array}{l}-0.172 \\
(-0.382)\end{array}$ & $\begin{array}{l}-0.147 \\
(-0.366)\end{array}$ & $\begin{array}{l}-0.240 \\
(-1.450)\end{array}$ & $\begin{array}{c}0.278 \\
(2.129)^{* *}\end{array}$ & $\begin{array}{l}0.180 \\
(0.932)\end{array}$ & $\begin{array}{c}0.224 \\
(1.753)^{*}\end{array}$ \\
\hline Netherlands & $\begin{array}{c}0.364 \\
(1.659)^{*}\end{array}$ & $\begin{array}{c}0.538 \\
(2.516)^{* *}\end{array}$ & $\begin{array}{c}0.213 \\
(2.017)^{* *}\end{array}$ & $\begin{array}{c}0.172 \\
(1.723)^{*}\end{array}$ & $\begin{array}{l}0.155 \\
(1.243)\end{array}$ & $\begin{array}{l}0.066 \\
(0.606)\end{array}$ \\
\hline Poland & $\begin{array}{l}-0.373 \\
(-0.914)\end{array}$ & $\begin{array}{c}-0.699 \\
(-1.995)^{* *}\end{array}$ & $\begin{array}{l}-0.174 \\
(-1.166)\end{array}$ & $\begin{array}{l}-0.106 \\
(-0.600)\end{array}$ & $\begin{array}{l}-0.244 \\
(-1.203)\end{array}$ & $\begin{array}{l}-0.205 \\
(-1.417)\end{array}$ \\
\hline Portugal & $\begin{array}{l}0.317 \\
(1.361)\end{array}$ & $\begin{array}{c}0.416 \\
(2.034)^{* *}\end{array}$ & $\begin{array}{c}0.341 \\
(3.212)^{* * *}\end{array}$ & $\begin{array}{c}0.266 \\
(3.003)^{* * *}\end{array}$ & $\begin{array}{l}0.198 \\
(1.604)\end{array}$ & $\begin{array}{l}0.122 \\
(1.051)\end{array}$ \\
\hline Romania & $\begin{array}{c}1.459 \\
(2.234)^{* *}\end{array}$ & $\begin{array}{l}0.560 \\
(0.781)\end{array}$ & $\begin{array}{l}0.026 \\
(0.112)\end{array}$ & $\begin{array}{l}0.224 \\
(1.499)\end{array}$ & $\begin{array}{l}0.313 \\
(1.432)\end{array}$ & $\begin{array}{l}0.147 \\
(0.503)\end{array}$ \\
\hline Slovakia & $\begin{array}{c}0.650 \\
(2.434)^{* *}\end{array}$ & $\begin{array}{c}0.532 \\
(2.544)^{* *}\end{array}$ & $\begin{array}{c}0.312 \\
(3.319)^{* * *}\end{array}$ & $\begin{array}{l}0.204 \\
(1.491)\end{array}$ & $\begin{array}{c}0.252 \\
(2.204)^{* *}\end{array}$ & $\begin{array}{l}0.131 \\
(0.691)\end{array}$ \\
\hline Spain & $\begin{array}{l}0.391 \\
(1.459)\end{array}$ & $\begin{array}{c}0.651 \\
(3.123)^{* * *}\end{array}$ & $\begin{array}{c}0.362 \\
(3.487)^{* * *}\end{array}$ & $\begin{array}{c}0.236 \\
(2.766)^{* * *}\end{array}$ & $\begin{array}{c}0.328 \\
(2.901)^{* * *}\end{array}$ & $\begin{array}{c}0.192 \\
(2.051)^{* *}\end{array}$ \\
\hline Sweden & $\begin{array}{l}0.246 \\
(0.984)\end{array}$ & $\begin{array}{c}0.713 \\
(2.223)^{* *}\end{array}$ & $\begin{array}{l}0.110 \\
(1.120)\end{array}$ & $\begin{array}{c}0.194 \\
(1.735)^{*}\end{array}$ & $\begin{array}{l}0.149 \\
(1.174)\end{array}$ & $\begin{array}{l}-0.114 \\
(-1.041)\end{array}$ \\
\hline UK & $\begin{array}{c}0.564 \\
(2.512)^{* *}\end{array}$ & $\begin{array}{l}0.076 \\
(0.272)\end{array}$ & $\begin{array}{l}0.049 \\
(0.490)\end{array}$ & $\begin{array}{l}0.130 \\
(1.140)\end{array}$ & $\begin{array}{l}-0.043 \\
(-0.328)\end{array}$ & $\begin{array}{l}-0.004 \\
(-0.030)\end{array}$ \\
\hline
\end{tabular}

Note: This table presents the estimates of the third element of the vector $\nabla^{\left(s_{t}\right)}$ and its associated $t$-statistic (in parentheses). These estimates are interpreted as the impact of upward and downward sovereign ratings drifts on the EU FX realized skewness as computed in formula (4). The sovereign ratings drifts, which represent the assessments of the CRAs on overall EU sovereign credit quality, are constructed as in formula (1) from ratings data provided by Standard and Poor's (S\&P), Fitch and Moody's. *, ** and *** denote significance at the 10,5 and $1 \%$ levels, respectively. 
Table 5a-Direct impact of sovereign rating drifts on the EU stock realized kurtosis

\begin{tabular}{|c|c|c|c|c|c|c|}
\hline \multirow{2}{*}{ Countries } & \multicolumn{3}{|c|}{ Upward rating drift } & \multicolumn{3}{|c|}{ Downward rating drift } \\
\hline & S\&P & Fitch & Moody's & S\&P & Fitch & Moody's \\
\hline \multirow[t]{2}{*}{ Austria } & -0.516 & -0.308 & 0.112 & -0.196 & -0.467 & -0.423 \\
\hline & $(-1.232)$ & $(-0.631)$ & $(1.014)$ & $(-1.308)$ & $(-3.650)^{* * *}$ & $(-5.133)^{* * *}$ \\
\hline \multirow[t]{2}{*}{ France } & -0.386 & -0.290 & 0.297 & -0.673 & -0.418 & -0.512 \\
\hline & $(-1.255)$ & $(-0.755)$ & $(1.541)$ & $(-4.689)^{* * *}$ & $(-2.368)^{* *}$ & $(-4.008)^{* * *}$ \\
\hline \multirow[t]{2}{*}{ Germany } & -0.475 & -0.446 & -0.061 & -0.455 & -0.180 & -0.019 \\
\hline & $(-1.380)$ & $(-1.636)$ & $(-0.302)$ & $(-2.369)^{* *}$ & $(-0.874)$ & $(-0.094)$ \\
\hline \multirow[t]{2}{*}{ Greece } & -1.736 & 0.879 & 0.374 & -0.155 & -0.821 & -1.060 \\
\hline & $(-3.064)^{* * *}$ & $(2.264)^{* *}$ & $(2.755) * * *$ & $(-0.683)$ & $(-3.891)^{* * *}$ & $(-6.451)^{* * *}$ \\
\hline \multirow[t]{2}{*}{ Ireland } & -0.335 & 0.675 & -0.039 & -0.191 & -0.346 & -0.432 \\
\hline & $(-0.883)$ & $(2.955)^{* * *}$ & $(-0.321)$ & $(-1.151)$ & $(-2.033)^{* *}$ & $(-3.247)^{* * *}$ \\
\hline \multirow[t]{2}{*}{ Netherlands } & -0.711 & -0.027 & 0.171 & -0.574 & -0.367 & 0.132 \\
\hline & $(-2.063)^{* *}$ & $(-0.059)$ & $(1.672)^{*}$ & $(-3.329)^{* * *}$ & $(-1.535)$ & $(1.172)$ \\
\hline \multirow[t]{2}{*}{ Spain } & -0.201 & -0.224 & 0.069 & 0.158 & 0.807 & 0.577 \\
\hline & $(-0.263)$ & $(-0.312)$ & $(0.307)$ & $(0.412)$ & $(2.680)^{* * *}$ & $(2.353)^{* *}$ \\
\hline \multirow[t]{2}{*}{ The UK } & 0.243 & 0.072 & 0.254 & -0.462 & -0.593 & -0.440 \\
\hline & $(0.363)$ & $(0.208)$ & $(2.804)^{* * *}$ & $(-3.763)^{* * *}$ & $(-2.928)^{* * *}$ & $(-3.150)^{* * *}$ \\
\hline \multirow[t]{2}{*}{ Hungary } & -0.066 & 0.269 & 0.117 & -0.126 & -0.650 & -0.318 \\
\hline & $(-0.171)$ & $(0.806)$ & $(0.783)$ & $(-0.560)$ & $(-3.215)^{* * *}$ & $(-1.648)^{*}$ \\
\hline \multirow[t]{2}{*}{ Romania } & 0.421 & 1.102 & -0.090 & 0.177 & -0.122 & 0.111 \\
\hline & $(0.946)$ & $(2.402)^{* *}$ & $(-0.429)$ & $(0.745)$ & $(-0.214)$ & $(0.384)$ \\
\hline
\end{tabular}

Note: This table presents the estimates of the fourth element of the vector $\nabla^{\left(s_{t}\right)}$ and its associated $t$-statistic (in parentheses). These estimates are interpreted as the impact of upward and downward sovereign rating drifts on the EU stock realized kurtosis as computed in formula (5). The sovereign rating drifts, which represent the assessments of the CRAs on overall EU sovereign credit quality, are constructed as in formula (1) from ratings data provided by Standard and Poor’s (S\&P), Fitch and Moody’s. *, ** and *** denote significance at the 10, 5 and 1\% levels, respectively. 
Table 5b-Direct impact of sovereign rating drifts on the EU FX realized kurtosis

\begin{tabular}{|c|c|c|c|c|c|c|}
\hline \multirow{2}{*}{ Countries } & \multicolumn{3}{|c|}{ U Upward rating drift } & \multicolumn{3}{|c|}{ "Downward rating drift } \\
\hline & S\&P & Fitch & Moody's & S\&P & Fitch & Moody's \\
\hline Austria & $\begin{array}{l}0.241 \\
(0.913)\end{array}$ & $\begin{array}{c}0.458 \\
(2.413)^{* *}\end{array}$ & $\begin{array}{l}0.084 \\
(0.669)\end{array}$ & $\begin{array}{l}-0.046 \\
(-0.451)\end{array}$ & $\begin{array}{l}-0.199 \\
(-1.234)\end{array}$ & $\begin{array}{l}-0.183 \\
(-1.410)\end{array}$ \\
\hline Belgium & $\begin{array}{l}0.134 \\
(0.432)\end{array}$ & $\begin{array}{c}0.461 \\
(1.989)^{* *}\end{array}$ & $\begin{array}{l}0.083 \\
(0.545)\end{array}$ & $\begin{array}{c}-0.282 \\
(-2.231)^{* *}\end{array}$ & $\begin{array}{c}-0.530 \\
(-2.964)^{* * *}\end{array}$ & $\begin{array}{c}-0.339 \\
(-2.471)^{* *}\end{array}$ \\
\hline Bulgaria & $\begin{array}{l}-0.073 \\
(-0.168)\end{array}$ & $\begin{array}{c}0.677 \\
(1.966)^{* *}\end{array}$ & $\begin{array}{l}-0.246 \\
(-0.915)\end{array}$ & $\begin{array}{l}0.074 \\
(0.393)\end{array}$ & $\begin{array}{l}-0.090 \\
(-0.374)\end{array}$ & $\begin{array}{l}-0.192 \\
(-0.837)\end{array}$ \\
\hline Cyprus & $\begin{array}{l}0.436 \\
(1.551)\end{array}$ & $\begin{array}{l}0.002 \\
(0.008)\end{array}$ & $\begin{array}{l}0.128 \\
(0.958)\end{array}$ & $\begin{array}{c}0.231 \\
(1.704)^{*}\end{array}$ & $\begin{array}{l}0.223 \\
(1.148)\end{array}$ & $\begin{array}{l}0.070 \\
(0.512)\end{array}$ \\
\hline Czech & $\begin{array}{c}0.830 \\
(2.384)^{* *}\end{array}$ & $\begin{array}{l}0.253 \\
(0.776)\end{array}$ & $\begin{array}{l}0.168 \\
(1.469)\end{array}$ & $\begin{array}{l}-0.124 \\
(-0.913)\end{array}$ & $\begin{array}{l}-0.107 \\
(-0.540)\end{array}$ & $\begin{array}{l}0.055 \\
(0.373)\end{array}$ \\
\hline Denmark & $\begin{array}{c}0.361 \\
(2.540)^{* *}\end{array}$ & $\begin{array}{l}0.201 \\
(0.736)\end{array}$ & $\begin{array}{l}0.044 \\
(0.351)\end{array}$ & $\begin{array}{l}-0.087 \\
(-0.716)\end{array}$ & $\begin{array}{l}0.026 \\
(0.158)\end{array}$ & $\begin{array}{l}-0.316 \\
(-2.733)\end{array}$ \\
\hline France & $\begin{array}{l}0.031 \\
(0.108)\end{array}$ & $\begin{array}{l}0.304 \\
(1.396)\end{array}$ & $\begin{array}{l}0.089 \\
(0.612)\end{array}$ & $\begin{array}{l}-0.163 \\
(-1.471)\end{array}$ & $\begin{array}{c}-0.456 \\
(-2.902)^{* * *}\end{array}$ & $\begin{array}{l}-0.134 \\
(-1.076)\end{array}$ \\
\hline Germany & $\begin{array}{l}0.112 \\
(0.501)\end{array}$ & $\begin{array}{c}0.319 \\
(1.702)^{*}\end{array}$ & $\begin{array}{l}0.106 \\
(1.245)\end{array}$ & $\begin{array}{l}-0.025 \\
(-0.246)\end{array}$ & $\begin{array}{l}-0.197 \\
(-1.640)\end{array}$ & $\begin{array}{c}-0.255 \\
(-2.404)^{* *}\end{array}$ \\
\hline Greece & $\begin{array}{l}0.375 \\
(1.562)\end{array}$ & $\begin{array}{c}0.397 \\
(1.927)^{*}\end{array}$ & $\begin{array}{l}0.003 \\
(0.023)\end{array}$ & $\begin{array}{c}-0.220 \\
(-2.092)^{* *}\end{array}$ & $\begin{array}{c}-0.468 \\
(-3.391)^{* * *}\end{array}$ & $\begin{array}{c}-0.421 \\
(-3.661)^{* * *}\end{array}$ \\
\hline Hungary & $\begin{array}{c}0.666 \\
(2.505)^{* *}\end{array}$ & $\begin{array}{l}0.296 \\
(1.021)\end{array}$ & $\begin{array}{c}0.429 \\
(3.732)^{* * *}\end{array}$ & $\begin{array}{l}-0.261 \\
(-1.429)\end{array}$ & $\begin{array}{c}-0.846 \\
(-4.224)^{* * *}\end{array}$ & $\begin{array}{c}-0.379 \\
(-1.983)^{* *}\end{array}$ \\
\hline Ireland & $\begin{array}{l}0.179 \\
(0.653)\end{array}$ & $\begin{array}{c}0.347 \\
(1.759)^{*}\end{array}$ & $\begin{array}{l}0.045 \\
(0.319)\end{array}$ & $\begin{array}{c}-0.321 \\
(-2.832)^{* * *}\end{array}$ & $\begin{array}{c}-0.633 \\
(-4.146)^{* * *}\end{array}$ & $\begin{array}{c}-0.321 \\
(-2.111)^{* *}\end{array}$ \\
\hline Latvia & $\begin{array}{l}-0.185 \\
(-0.785)\end{array}$ & $\begin{array}{c}-0.396 \\
(-1.752)^{*}\end{array}$ & $\begin{array}{l}-0.015 \\
(-0.136)\end{array}$ & $\begin{array}{l}-0.008 \\
(-0.064)\end{array}$ & $\begin{array}{l}0.086 \\
(0.711)\end{array}$ & $\begin{array}{l}0.161 \\
(1.419)\end{array}$ \\
\hline Malta & $\begin{array}{l}0.363 \\
(0.765)\end{array}$ & $\begin{array}{c}0.922 \\
(2.449)^{* *}\end{array}$ & $\begin{array}{l}0.108 \\
(0.606)\end{array}$ & $\begin{array}{c}-0.345 \\
(-1.840)^{*}\end{array}$ & $\begin{array}{l}-0.455 \\
(-1.427)\end{array}$ & $\begin{array}{c}-0.414 \\
(-2.115)^{* *}\end{array}$ \\
\hline Netherlands & $\begin{array}{l}0.091 \\
(0.391)\end{array}$ & $\begin{array}{c}0.382 \\
(1.689)^{*}\end{array}$ & $\begin{array}{l}0.094 \\
(0.889)\end{array}$ & $\begin{array}{l}0.016 \\
(0.155)\end{array}$ & $\begin{array}{l}-0.175 \\
(-1.250)\end{array}$ & $\begin{array}{c}-0.320 \\
(-2.697)^{* * *}\end{array}$ \\
\hline Poland & $\begin{array}{l}0.305 \\
(0.621)\end{array}$ & $\begin{array}{l}0.569 \\
(1.529)\end{array}$ & $\begin{array}{l}0.068 \\
(0.332)\end{array}$ & $\begin{array}{l}-0.232 \\
(-1.323)\end{array}$ & $\begin{array}{c}-0.654 \\
(-3.577)^{* * *}\end{array}$ & $\begin{array}{l}-0.061 \\
(-0.317)\end{array}$ \\
\hline Portugal & $\begin{array}{l}0.389 \\
(1.224)\end{array}$ & $\begin{array}{l}0.306 \\
(1.066)\end{array}$ & $\begin{array}{l}0.081 \\
(0.506)\end{array}$ & $\begin{array}{c}-0.308 \\
(-2.074)^{* *}\end{array}$ & $\begin{array}{c}-0.465 \\
(-2.964)^{* * *}\end{array}$ & $\begin{array}{c}-0.413 \\
(-2.560)^{* *}\end{array}$ \\
\hline Romania & $\begin{array}{l}-0.717 \\
(-0.996)\end{array}$ & $\begin{array}{l}-0.080 \\
(-0.097)\end{array}$ & $\begin{array}{l}-0.116 \\
(-0.357)\end{array}$ & $\begin{array}{l}-0.308 \\
(-0.825)\end{array}$ & $\begin{array}{c}-0.831 \\
(-2.429)^{* *}\end{array}$ & $\begin{array}{l}-0.434 \\
(-1.295)\end{array}$ \\
\hline Slovakia & $\begin{array}{c}0.736 \\
(2.909)^{* * *}\end{array}$ & $\begin{array}{l}0.355 \\
(1.383)\end{array}$ & $\begin{array}{l}0.090 \\
(0.647)\end{array}$ & $\begin{array}{l}-0.127 \\
(-0.902)\end{array}$ & $\begin{array}{l}0.007 \\
(0.047)\end{array}$ & $\begin{array}{l}-0.205 \\
(-1.340)\end{array}$ \\
\hline Spain & $\begin{array}{l}0.291 \\
(0.889)\end{array}$ & $\begin{array}{l}0.151 \\
(0.537)\end{array}$ & $\begin{array}{l}0.107 \\
(0.647)\end{array}$ & $\begin{array}{c}-0.391 \\
(-3.104)^{* * *}\end{array}$ & $\begin{array}{c}-0.613 \\
(-3.234)^{* * *}\end{array}$ & $\begin{array}{c}-0.413 \\
(-3.040)^{* * *}\end{array}$ \\
\hline Sweden & $\begin{array}{c}0.403 \\
(1.882)^{*}\end{array}$ & $\begin{array}{c}0.348 \\
(2.008)^{* *}\end{array}$ & $\begin{array}{l}0.113 \\
(1.115)\end{array}$ & $\begin{array}{l}-0.027 \\
(-0.241)\end{array}$ & $\begin{array}{l}-0.172 \\
(-0.975)\end{array}$ & $\begin{array}{c}-0.257 \\
(-2.407)^{* *}\end{array}$ \\
\hline UK & $\begin{array}{c}0.340 \\
(1.666)^{*}\end{array}$ & $\begin{array}{c}0.370 \\
(2.102)^{* *}\end{array}$ & $\begin{array}{l}0.084 \\
(0.771)\end{array}$ & $\begin{array}{l}0.042 \\
(0.371)\end{array}$ & $\begin{array}{l}-0.145 \\
(-1.127)\end{array}$ & $\begin{array}{l}-0.123 \\
(-1.187)\end{array}$ \\
\hline
\end{tabular}

Note: This table presents the estimates of the fourth element of the vector $\nabla^{\left(s_{t}\right)}$ and its associated $t$-statistic (in parentheses). These estimates are interpreted as the impact of upward and downward sovereign rating drifts on the EU FX realized kurtosis, as computed in formula (5). The sovereign rating drifts, which represent the assessments of the CRAs on overall EU sovereign credit quality, are constructed as in formula (1) from ratings data provided by Standard and Poor's (S\&P), Fitch and Moody's. *, ** and *** denote significance at the 10,5 and $1 \%$ levels, respectively. 